\title{
Drawing the scientific map of Islamic Azad University Medical Sciences products in Web of Science site
}

Fereshteh Souri', ${ }^{1}$ Yaghob Nourozi ${ }^{2}$, Seyed AliAkbar Familrohany ${ }^{3}$, Atefeh Zarei ${ }^{4}$

${ }^{I}$ PhD Student, PhD Student, Department of Information Science, Hamedan Branch, Islamic Azad University, Hamedan, Iran

${ }^{2}$ Associate Professor, Faculty Member, Department of Information Science, University of Qom

${ }^{3}$ Assistant Professor, Department of Information Science, Hamedan Branch, Islamic Azad University, Hamedan, Iran

${ }^{4}$ Assistant Professor, Department of Information Science, Hamedan Branch, Islamic Azad University, Hamedan, Iran

\begin{abstract}
Background: The aim of this research was to analyze and illustrate scientific productions of Islamic Azad University researchers under title of Medical Sciences in Web of Science (WOS) data base.

Materials and methods: The present study was a kind of applied scientific research which studied the quantitative performance of Islamic Azad University of Medical Sciences in WOS database from beginning to 2018. Statistical population of this study was all scientific productions of Medical Sciences of Islamic Azad University (11155 records) in WOS database.

Results: The first scientific output of medical sciences of Islamic Azad University was indexed in 1996 and the highest number of indexed output was in 2016. Kazem Parivar has been ranked the first among all researches and had the highest scientific collaboration was with the USA academic centers. The journal "African Journal of Biotechnology" was also recognized as the source of the medical science core of the Islamic Azad University on the Web of Science. The most frequently use key word was "Iran" and key words "Pharmaceutical Chemistry" and "Pharmacology and Pharmacy" had the most frequent synonyms. Finally, the keywords of Islamic Azad University's scientific productions in medical sciencesweare divided into 7 general clusters.

Conclusion: The results of this study indicate that Islamic Azad University of Medical Sciences researchers have been able to obtain the third rank among the medical universities of Iran with a good effort. But they have not used their potential to recognize Iran's progress in controlling the spread of communicable diseases worldwide.

Keywords: Scientometrics, Scientific products, Clustering, Web of Science database, Medical sciences, Islamic Azad University.
\end{abstract}

Cited as: Souri F, Nourozi Y, Familrohany SAA, Zarei A. Drawing the scientific map of Islamic Azad university Medical Science products in Web of Science site. Medical Science Journal of Islamic Azad University, Tehran Medical Branch 2020; 30(2): 204-220.

Correspondence to: Yaghob Nourozi

Tel: +989122187688

E-mail: ynorouzi@gmail.com

ORCID ID: 0000-0003-3030-7647

Received: 22 Jun 2019; Accepted: 13 Sep 2019 
مجله علوم يزشكى دانشعاه آزاد اسلامى

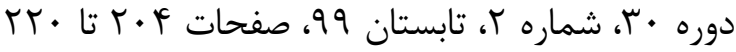

\section{ترسيم نقشه علمى توليدات علوم يزشكى دانشعاه آزاد اسلامى در يايگاه وب آو ساينس}

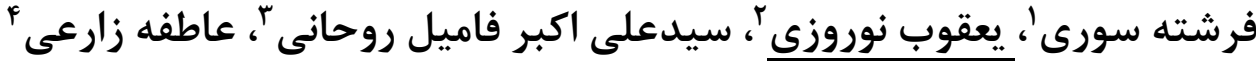

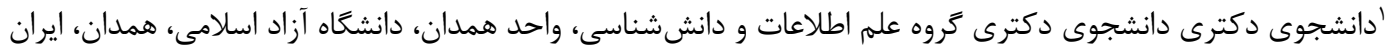

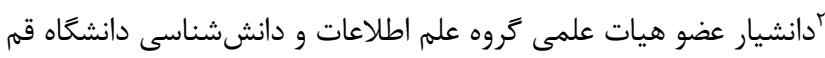

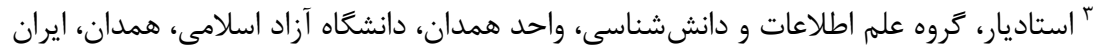

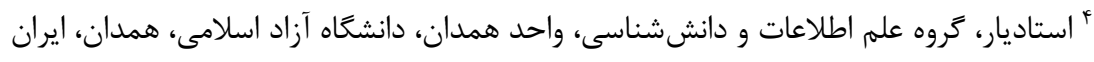

جـكيده

سابقه و هدف: هدف /ين يثوهش تحليل و مصورسازى توليدات علمى بزوهشكران دانشكاه آزاد /سلامى در موضوع علوم يزشكى در

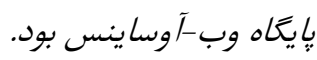

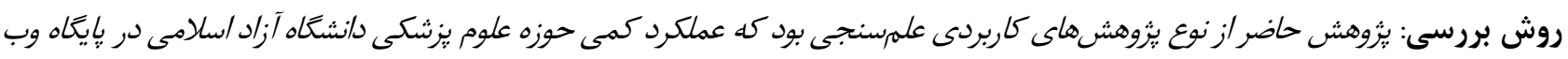

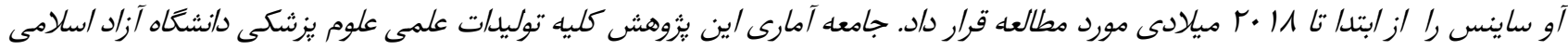

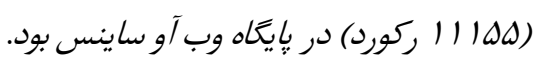

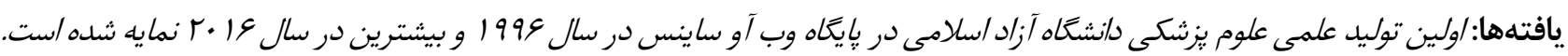

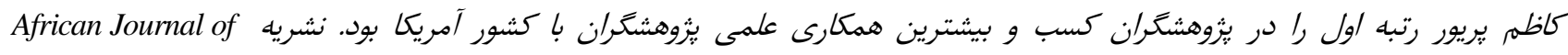
Biotechnology

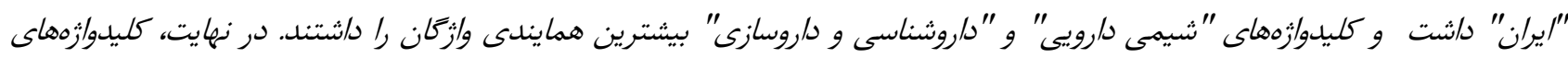

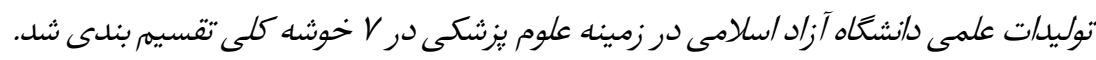

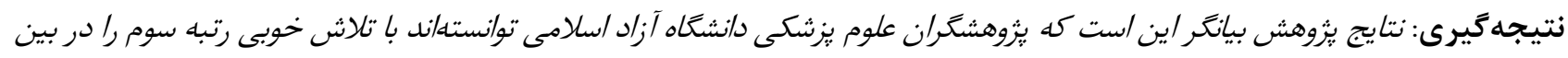

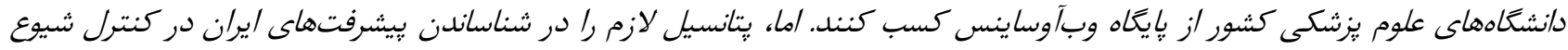
بيمارىهاى مسرى در سطح جهانى صرف نكردهاند.

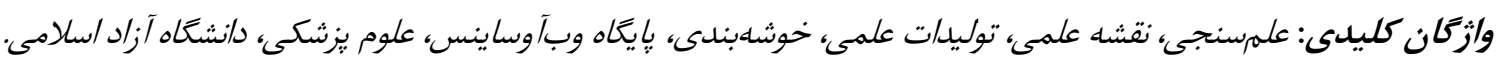

آموزشى و تحقيقاتى محسوب مى شوند و توسعه كمى و كيفى

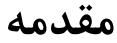
آنها به لحاظ اهميت توليد علم در توسعه جوامع داراى اولويت

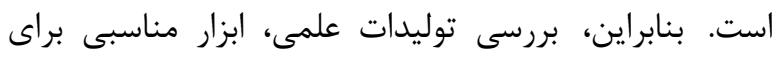

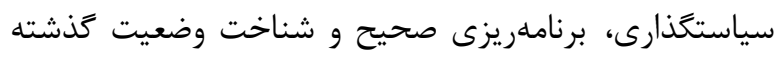

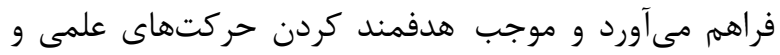

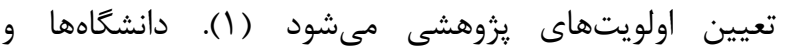

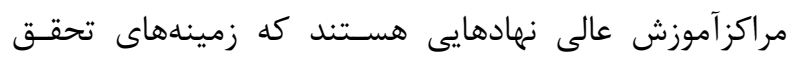

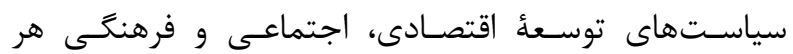
أدرس نويسنده مسئول: ، عضو هيات علمى گروه علم اطلاعات و دانشش شناسى دانشخاه قـم ، يعقوب (email: ynorouzi@gmail.co) نورون ORCID ID: 0000-0003-3030-7647

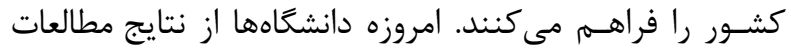

توليد علم، ركن اصلى تمام برنامهها براى نيل به توسعه بِايدار

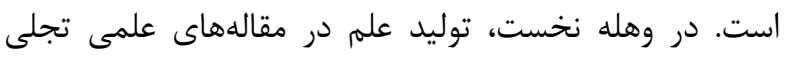

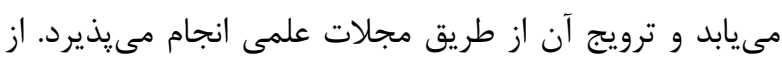

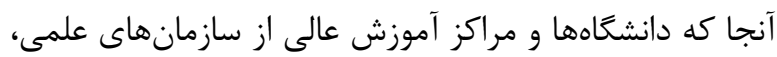


سنجى به مديران دانشعاهها و روساى مراكز يزوهشى در

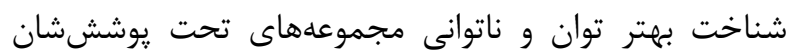

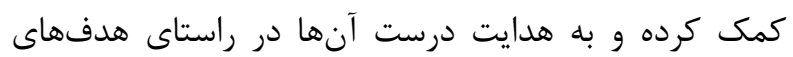

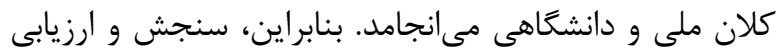
علم (علمسنجى) واقعيتى است كه در كذشته و حال در سطح

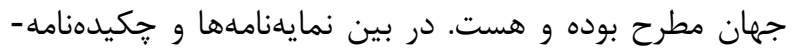
هاى موجود، نمايه استنادى آى.اس.آى (ISI) مشهورترين و

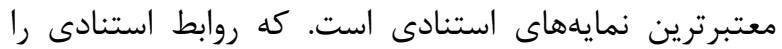
ترسيم و امكان سنجش كمى و كيفى توليدات علمى را با

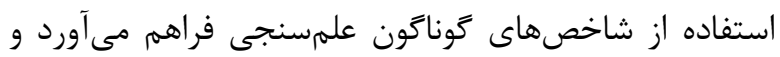
زمينهى مناسبى جهت ارزيابى و سنجش دستاوردها و و انتشارات علمى كشورها به شمار مىرود.

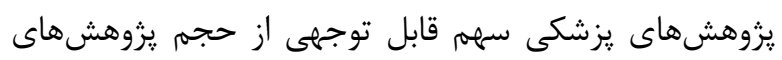

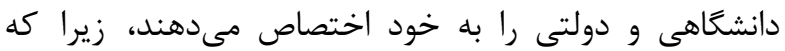

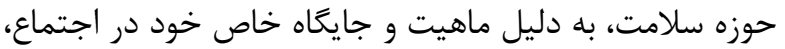

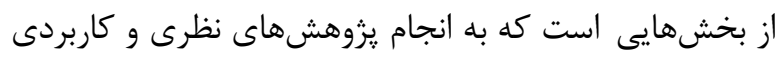
در حوزههاى مختلف بهداشت و يزشكى توجه زيادى نشان بنان مى دهد. از سوى ديكر، حوزه يزشكى همه ساله يزوهشهاى

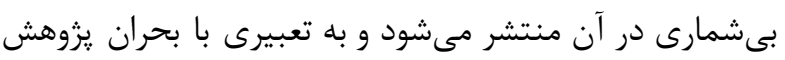

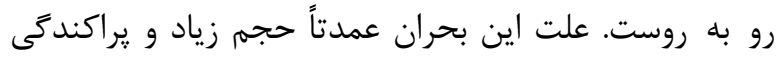

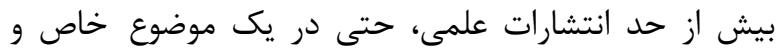

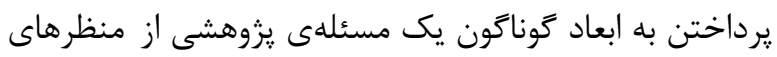

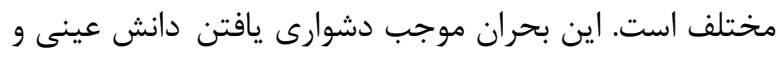

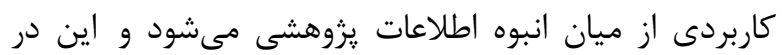
حالى است كه هدف از يزوهش علمى حصول به دان دانش عينى و إنى

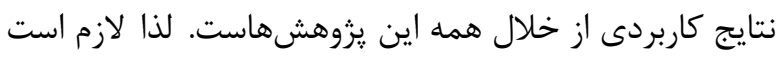

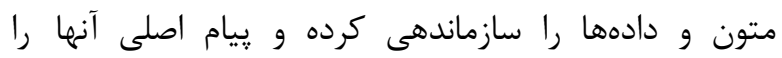
استخراج نموده و به كمك روشهاى تلخيص مطالعات انجام

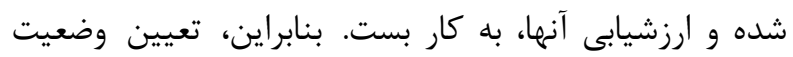

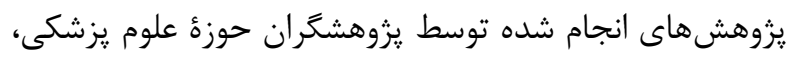
علاوه بر اينكه سطح توانمندى علمى و ميزان تأثير آنان را درد توسعة علمى نشان مىدهد، مى تواند به عنوان معيار مناسبى با هدف ارزيابى علمى اين گروه، براى ارتقاى علمى مورد توجه تونه

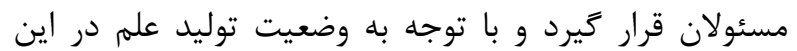
حوزه مى توان به تعيين جايگاه اين حوزه از لحاظ توليد علم در درد سطح كشور يرداخت.

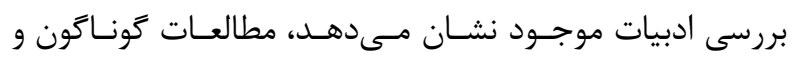

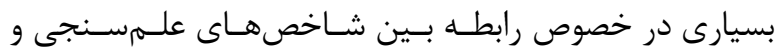

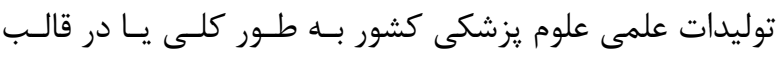
دانشخاههاى مختلف در يايكاههاى اطلاعـاتى تونـاكون انجـام
علمسنجى در سطوح مختلف اعم از خرد و كلان در عرصه

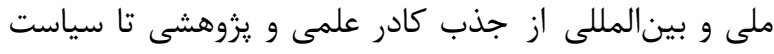

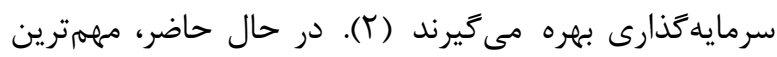
شاخص توليد علم دانشكاهها، تعداد مدارك نمايه شده از مجلات علمى در يايكاههاى اطلاعاتى است كه موضوع بحث

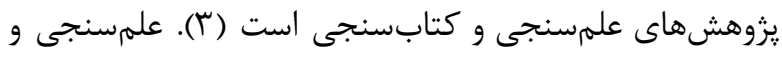

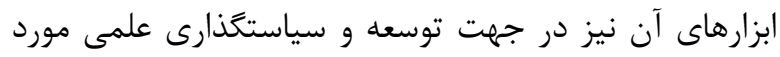

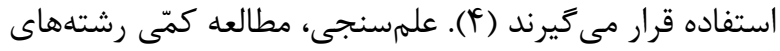

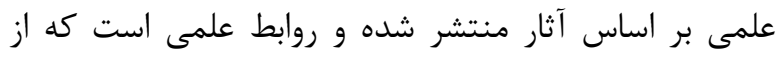

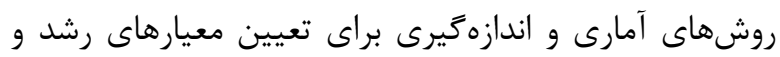

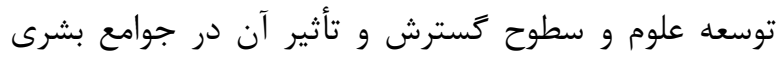
استفاده مى كند (b). علمسنجى، به دليل نقشى كه در در زمينه

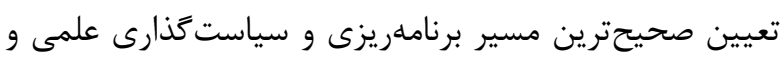
فناورى بر عهده دارد، از جايخاه برجستهاى برخوردار شده

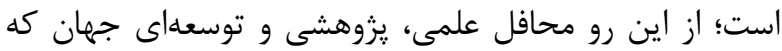

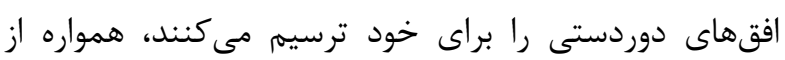

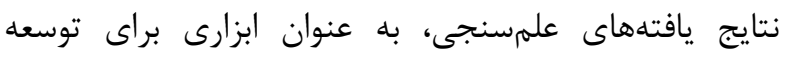

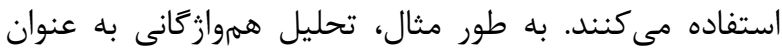

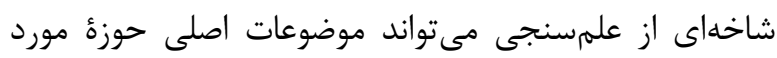

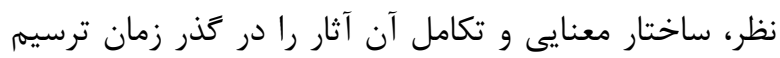

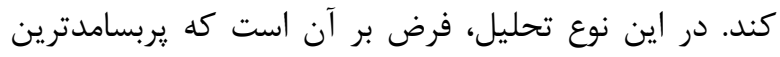

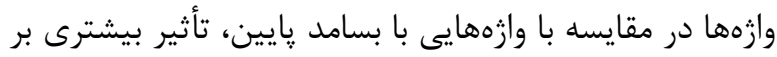

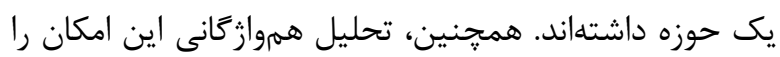

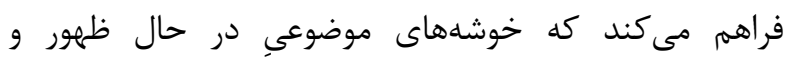
همجِنين خوشههاى توسعهيافته را در راستاى بِيشبينى مسير

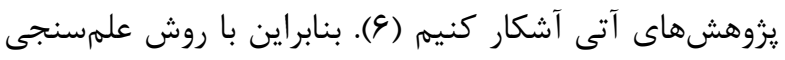

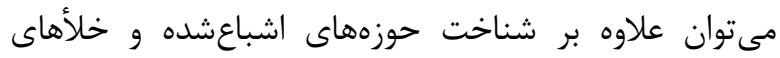
موضوعى موجود (ساختار دانش) در حوزه از نظر يزونش

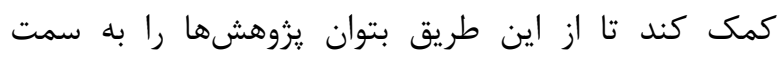

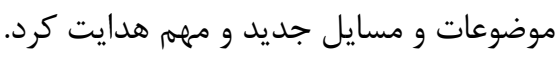

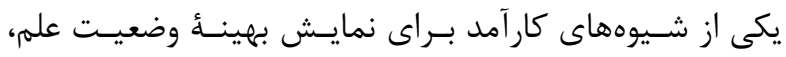

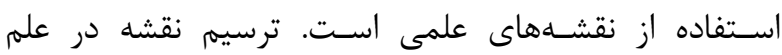

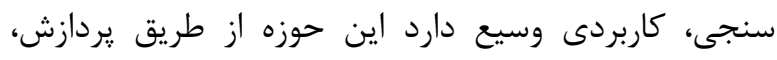
استخراج و مرتبسازى اطلاعات به ترسيم نقشه علم مى يردازئ

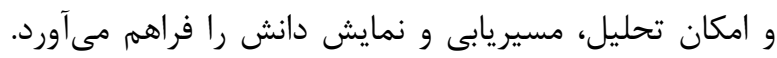

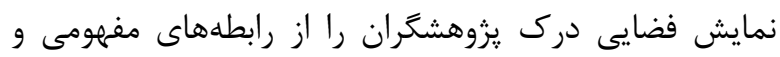

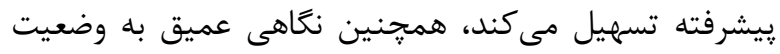
دانش معاصر را در قلمروهاى كوناكون علمى فراهم مى كند. از طرفى هم شناخت توليد علمى يزوهشكران و اعضاى هرئ هيات

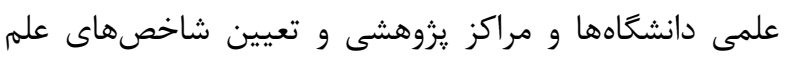


يزوهشى ساختار انتشارات علمى توليد شده اعضاى هيـات علمسى

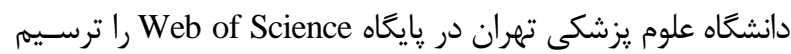

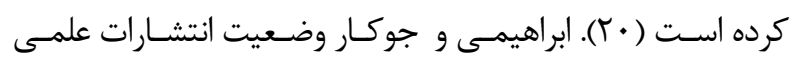

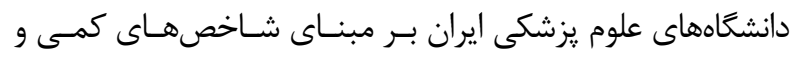

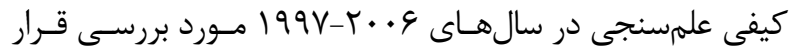

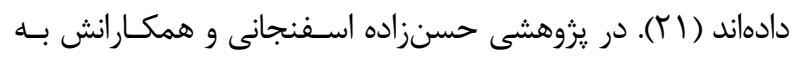
بررسى و تحليلى بر توليدات علمى ايران در حوزه علوم يزشكى بــهـ

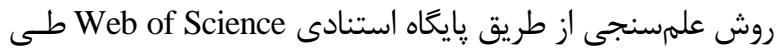

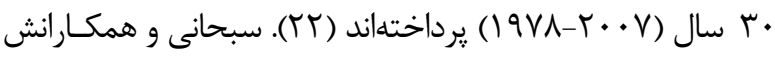
در يزروهشى وضعيت توليد مقـالات علمسى توسـط اعضـاى هيـات علمى دانشگاه علوم يزشكى گيلان مورد بررسى قرار دادهاند (Tr). گرجى و همكارانش در يزوهشـى اعضـاى هيـأت علمـى دانشـعاه

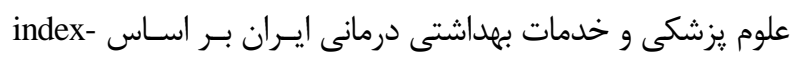

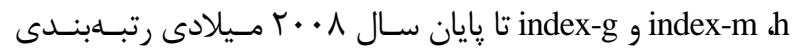
كردند (YY). فروغى و خرازى هم وضعيت توليـد اطلاعـات علمسى

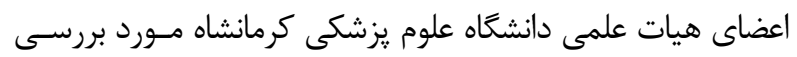

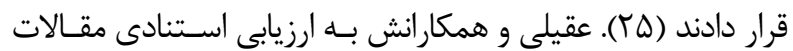
جاب شده در مجلات علمى - يزوهشى دانشخاههاى علـوم يزشـكى

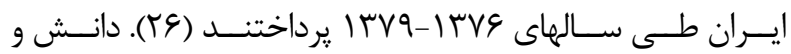
همكارانش در سال 9 × . ب ميلادى به ترسيم نقشه علمى محققـان

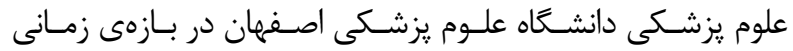

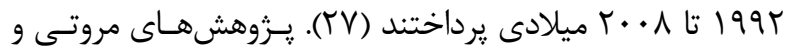

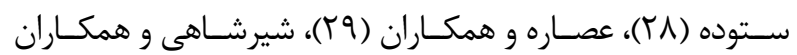

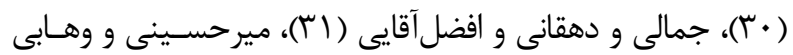

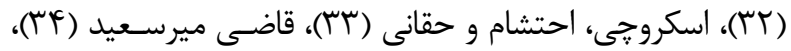

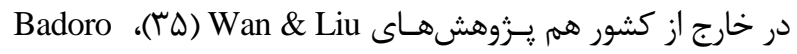

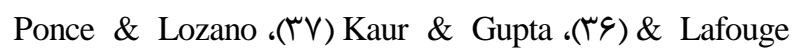

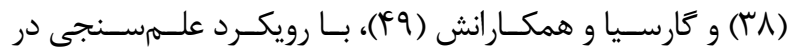

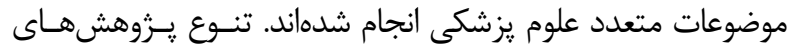

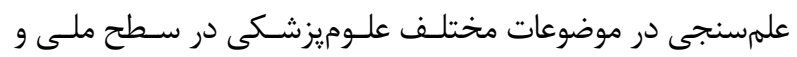

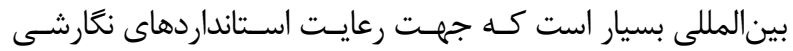

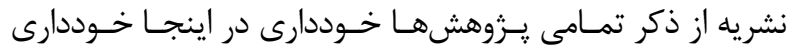

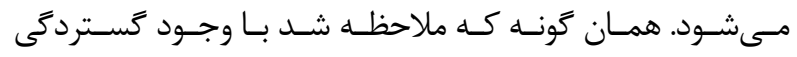

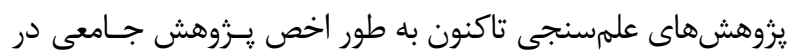
بررسى توليدات علمى علوم يزشكى دانشـعاه آزاد اسـلامى انجـام

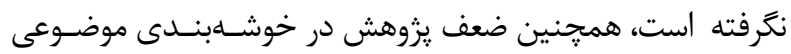
توليدات علمى علوم يزشكى ديده مىشود.

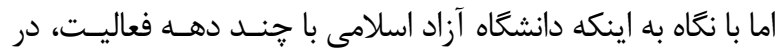
موقعيتى حياتى از تاريخ وجودى خود به سر مىبرد و سالانه صدها فارغالتحصيل در علوم يزشكى دارد و تاكنون مطالعـه جـامعى بــر
گرفته شده است، همجنين گَستردگى موضوعات علوم يزشكى هم اين گوناگونى را بيشتر كرده است و از اين لحـاظ در ابتـدا جديدترين و مرتبطترين يزوهشهاى علمسنجى كه به صورت

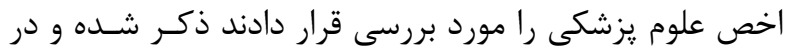

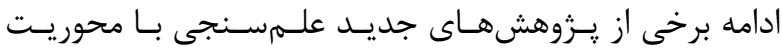

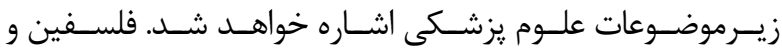
همكارانش به بررسى توليدات علمى يزشكى ايران در پايعاه Web of Science وكيلىمفرد و حسينىراد در يزوهشى به بررسـى كمى توليـدات

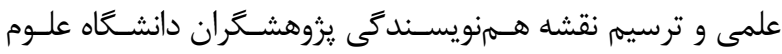
يزشكى همدان در يايگاه استنادى Scopus يرداختند (^). تركمان

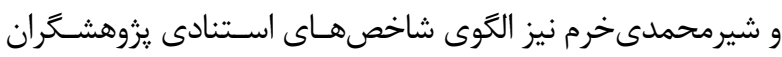

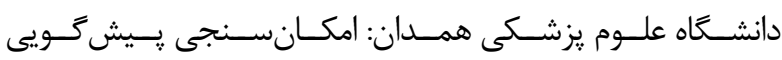
شاخصهاى علمسنجى، را مورد بررسى قرار دادند (9). شـبانكاره و

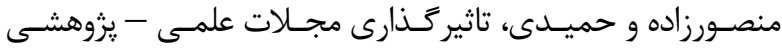

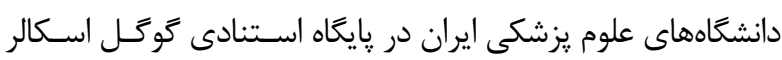

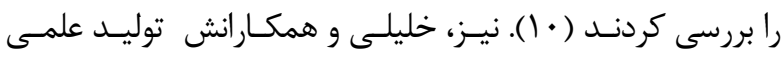

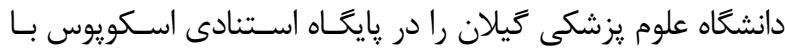
شاخصهاى علمسنجى را بررسى كردند (1)). ستارزاده وگلينسى - (1)

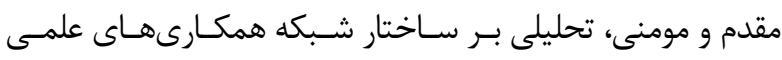

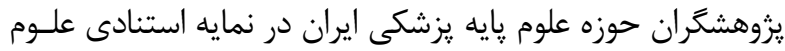

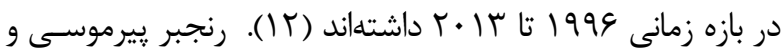

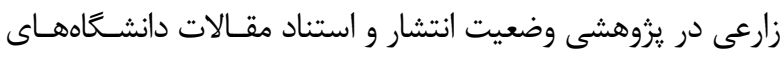

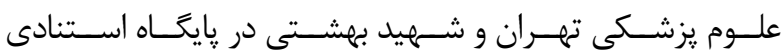

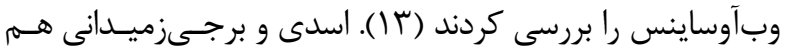
روابط علمى مراكز تحقيقات علوم يزشكى استان گيلان را تحليـل

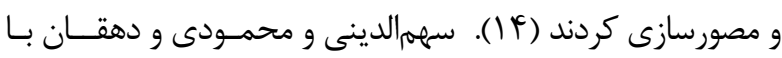
Scopus استفاده ازشاخصهاى علـمســنجى در يايخـاه اسـتنادى

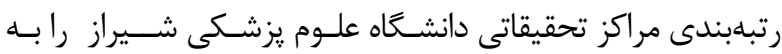
انجام رساندهاند (ه ()). شكفته و حريرى، نقشه علمى يزشكى ايران با اسـتفاده از روش هـم اسـتنادى موضـوعى و معيارهـاى تحليـل

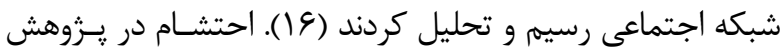

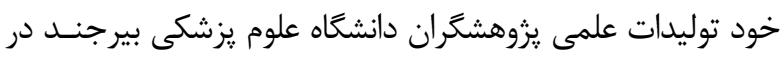

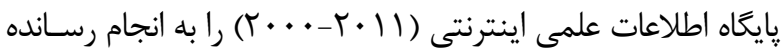

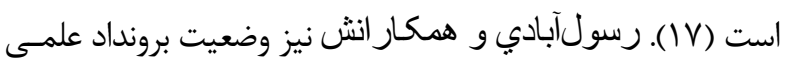
دانشعاه علوم يزشكى كردستان بر اساس شاخصهاى علـمسـنجى

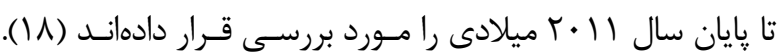
مباشرى و همكارانش برونداد علمى دانشگاه علوم يزشكى شهركرد

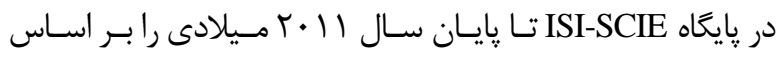

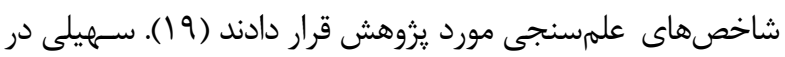




\section{مواد و روشها}

يزوهش حاضر از نوع كاربردى است كه با رويكرد علمسنجى انجام

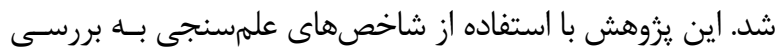

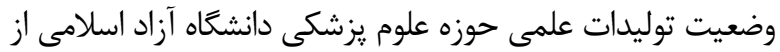

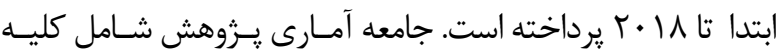

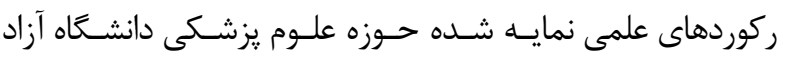

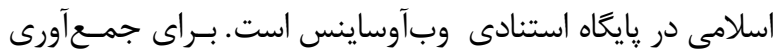
دادهها، از فرمول تركيبى جستجوى زير در اين زايگاه استفاده شد. $\mathrm{AD}=$ "Islamic azad university" OR OG= "Islamic azad university" OR OO= "Islamic azad university" OR SG= "Islamic azad university" از آنجا كه تمامى واحدهاى علوم يزشكى دانشـعاه آزاد اسـلامى در

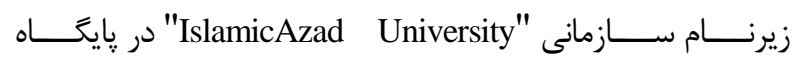
وبآوساينس نمايه شدهاند. همجنين در راستاى جستجوى جامع و مانع در يايگاه مذكور از فرمول ذكرشده در روش تحقيـق مقالـه

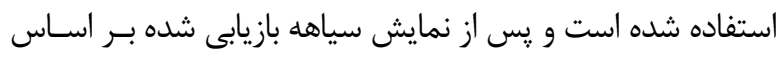

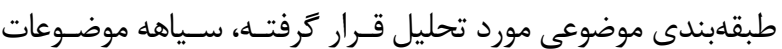
مربوط به علوم يزشكى در يايگاه گزينش شد. موضوعات بـه شـرح

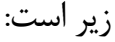

Biotechnology Applied Microbiology, Pharmacology Pharmacy, Medicine General , Internal, Chemistry Medicinal, Microbiology, Medicine Research Experimental, Engineering Biomedical, Neurosciences, Oncology, Toxicology, Dentistry Oral Surgery Medicine, Immunology, Spectroscopy, Radiology Nuclear Medicine, Medical Imaging, Imaging Science Photographic Technology, Obstetrics Gynecology, Clinical Neurology, Genetics Heredity, Endocrinology Metabolism, Surgery, Infectious Diseases, Medical Laboratory Technology, Integrative Complementary Medicine, Cardiac Cardiovascular Systems, Parasitology, Gastroenterology Hepatology, Peripheral Vascular Disease, Pathology, Urology Nephrology, Dermatology, Mycology, Allergy, Health Care Sciences Services, Hematology, Nursing, Virology, Rehabilitation, Medical Informatics, Orthopedics, Anatomy Morphology, Emergency Medicine, Health Policy Services, Andrology, Ophthalmology, Otorhinolaryngology, Rheumatology, Respiratory System, Cell Tissue Engineering, Critical Care Medicine, Ergonomics, Anesthesiology, Geriatrics Gerontology, Gerontology, Medicine Legal, Medical Ethics, Primary Health Care, Neuroimaging, Psychiatry.

يس از نمـايش نتـايج، ركوردهـاى نمايـه شـده در زيـر مجموعـهـ

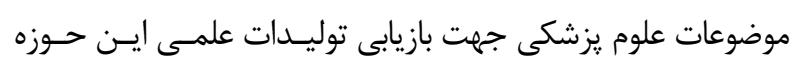

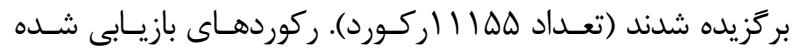

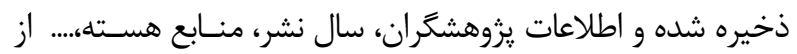

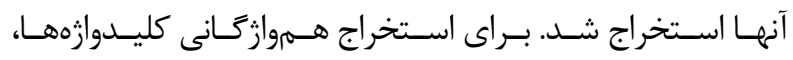
ركوردهاى بازيابى شده با فرمست يلـن تكسـ (Plaint txt) ذخيـره
توليدات حوزه علـوم يزشـكى دانشــاه آزاد اسـلامى را در يايخــاه

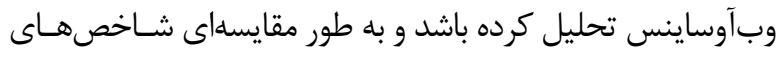

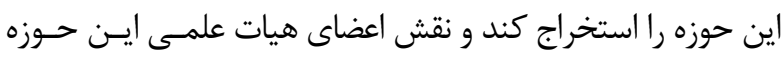

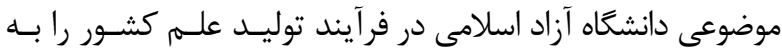
عنوان يك يزوهش مستقل مورد مطالعه قرار دهد صـورت نخرفتـه

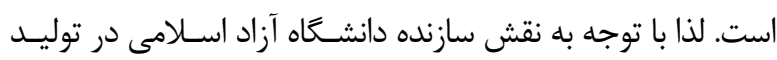

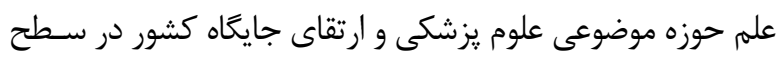
جهانى، در اين :يزوهش سعى شده است مواردى از قبيـل وضـعيت

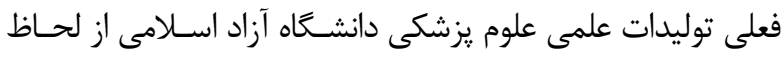

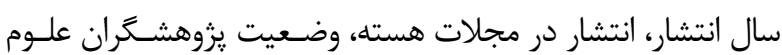
يزشكى دانشگاه آزاد اسلامى در سطح ملى و بينالمللى، وضـعيت

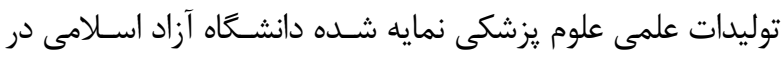

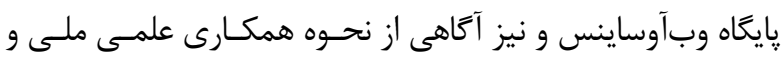

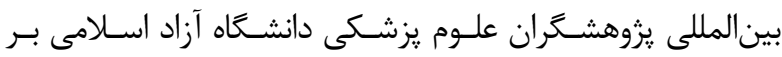

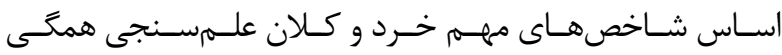

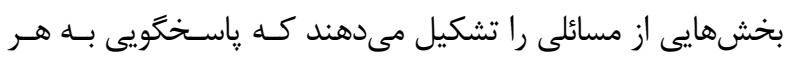

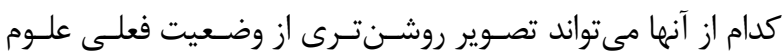

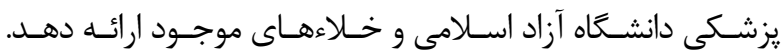
بنابراين، مسئله اصلى يزوهش ايـن اسـت كـهـ وضـعيت توليـدات

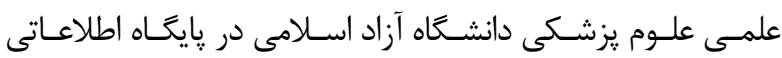

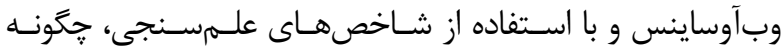

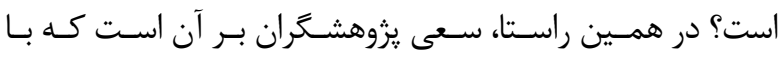

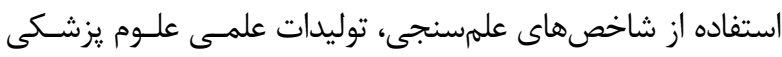

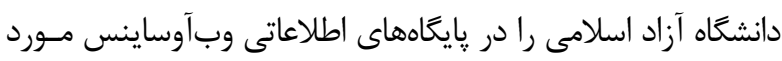
بررسى قرار دهد و جهت دستيابى به اين اهداف سوالات يـرثوهش به شرح زير است:

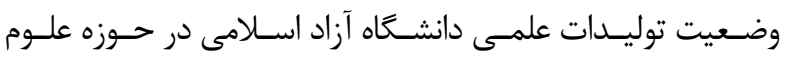
يزشكى از لحاظ سال انتشار در يايگاه وبآوساينس جَّونه اسـت؟

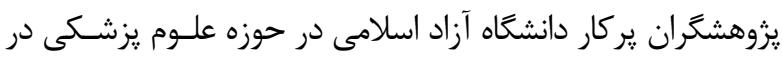

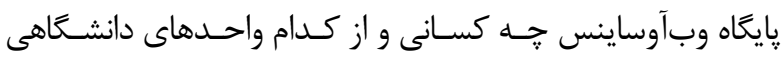

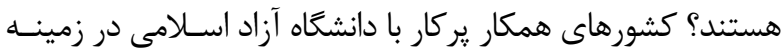
موضوعى علـوم :زشـكى در يايخـاه وبآوسـاينس كـدام كشـورها هستند؟ منابع هسته در نشر يافتههاى علمى يزروهشكَران دانشـعاه

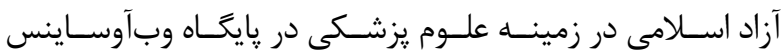
كدامند؟ يربسامدترين كليدوازه و بالاترين همرخدادى كليدوازه هـا در زمينه موضوعى علوم يزشـكى دانشـعاه آزاد اسـلامى در يايخــاه

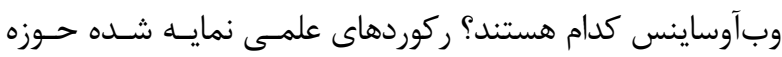

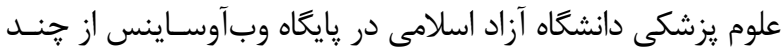
خوشه تشكيل شده است و هر خوشه شـامل جــه كليـدوازههـايى 


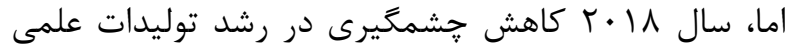

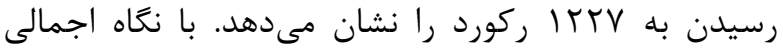

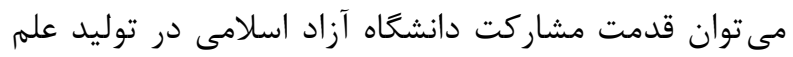
در زمينه علوميزشكى را در سطح بينالمللى ملاحظه كرد.

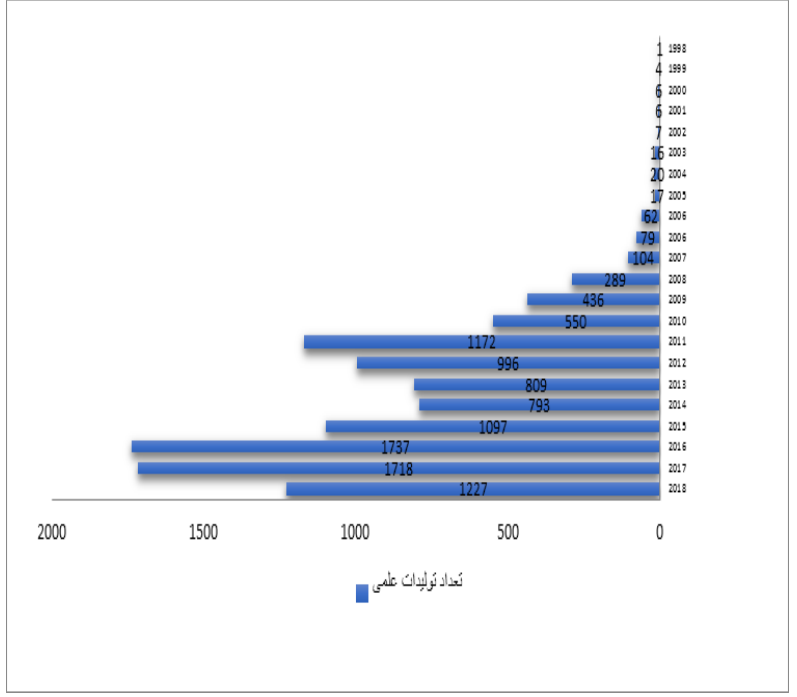

نمودار 1. توليدات علمى حوزه علوم يزشكى دانشكاه آزاد

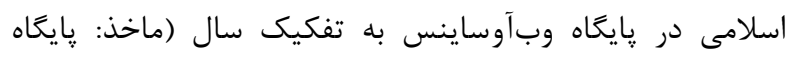

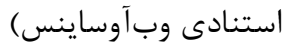

يرسش دو: يزوهشكران گركار دانشگاه آزاد اسلامى در

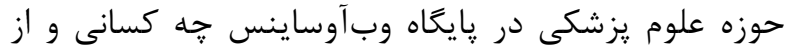

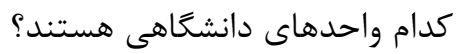
از شاخصهاى توسعه بايدار، اهميت و ارزشدهى به توليد علم در كشور است و مسئوليت توسعه تحقيقات و توليد علم بر عهره دانشكاهها مىباشد كه با توجه به به امكانات،

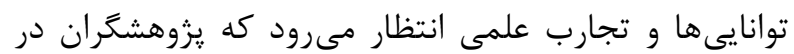

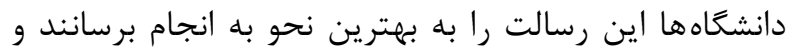

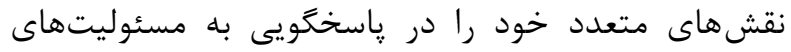

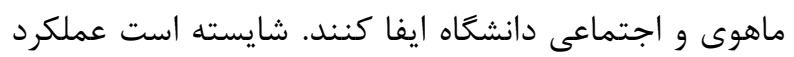
علمى يزوهشكَران سنجيده شود تا هر حوزه علمى دانشكاه

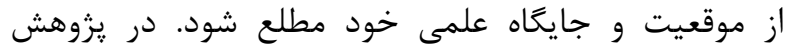
حاضر نظر به تاكيد بر دانشعاه آزاد اسلامى در جادئاه آمارى :زوهش، جهت فهرست نمودن :زوهشكران : يركار

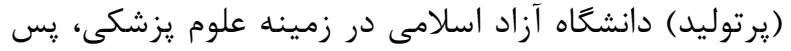

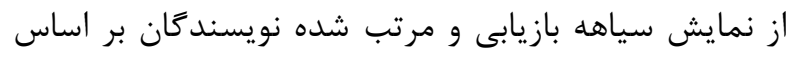

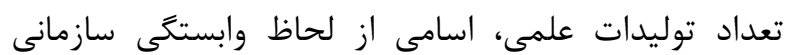

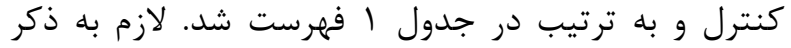

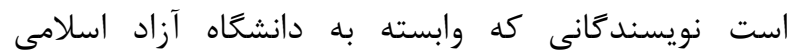

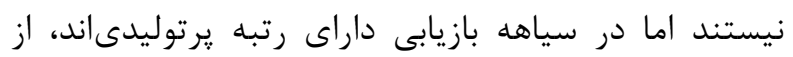
فهرست حذف شدند. بنابراين جدول البر اساس تعداد
شده و سـيس بــا اسـتفاده از نـرمافززار بيـبـ اكسـل (BibExcel)

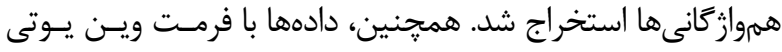

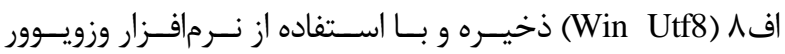
(VosViewer) خوشهبندىها استخراج شدند. سيس، جهت ترسيم نقشـه علمى بـى

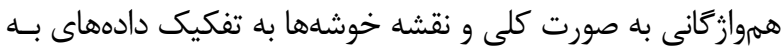

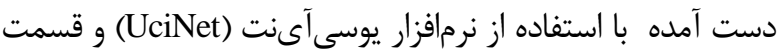
نت درايو (Netdraw) فراخوانى شده و نقشههاى مربوطه و ارتبـاط

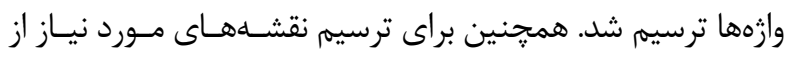

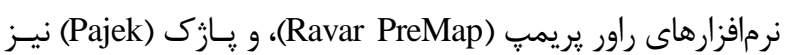
استفاده شده است.

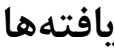

در اين قسمت به يرسشهاى يزوهش، از جمله وضعيت

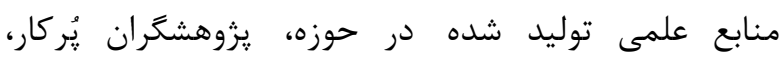

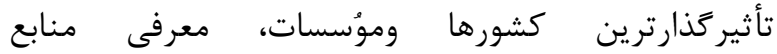

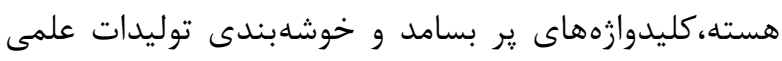

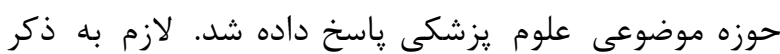

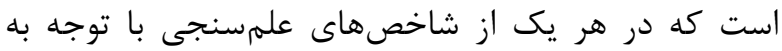

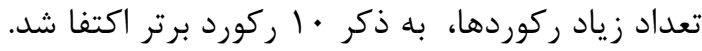

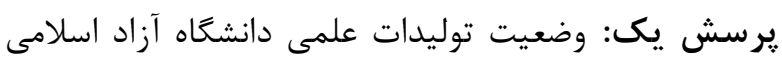
در حوزه علوم يزشكى از لحاظ سال انتشار در بإيكاه

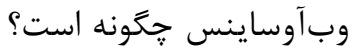
در ترسيم نقشه موضوعى يك حوزه از دانش، استفاده از

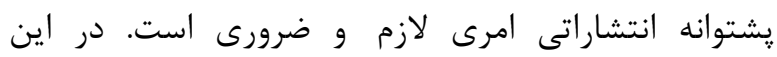
يزوهش، تمامى توليدات علمى دانشعاه آزاد اسلامى كه در التر

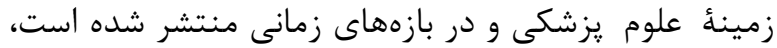

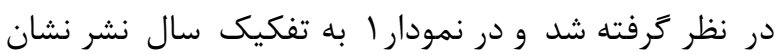

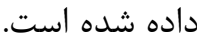
همانطور كه در نمودار 1 ملاحظه مى شود، اولين توليد علمى

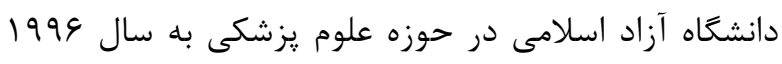

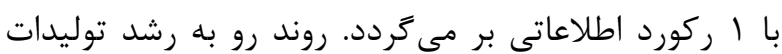
علمى به صورت نرم و آهسته جلو رفته تا اينكه در سال

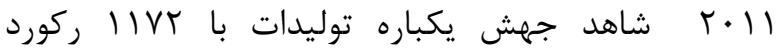
هستيم و با كمى اختلاف توليدات ادامه دارد كه دي در سال

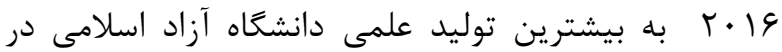
حوزه علوم يزشكى با تعداد IVYV , ركورد نشان داده

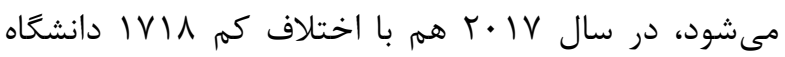
آزاد اسلامى ركورد توليد علمى علوم يزشكى داشته است. 
جدول ا. يزوهشكَر يركار حوزهُ موضوعى علوم يزشكى از دانشكاه آزاد اسلامى در يايكاه وبآوساينس

\begin{tabular}{|c|c|c|c|c|c|c|c|c|}
\hline طبقهبندى موضوعى در پاييًاه وب- & $\begin{array}{l}\frac{T}{10} \\
\frac{1}{3}: \\
3 \\
3 \\
3\end{array}$ & 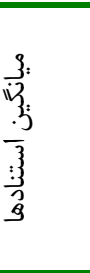 & $\begin{array}{ll}3 & \\
\frac{3}{3} & \\
3 & \\
3 & \overline{3} \\
3 & 3 \\
9 & 3 \\
3 & 3 \\
.5 & \\
.3 & \\
1 & \\
0 & \end{array}$ & $\begin{array}{l}\frac{3}{3} \\
\frac{3}{3} \\
3 \\
3 \\
3 \\
9\end{array}$ & $\begin{array}{l}\frac{3}{3} \\
\frac{3}{3} \\
3 \\
\vdots 3 \\
\vdots 3 \\
\vdots 3\end{array}$ & واحد دانشَاهى دانشعاه آزاد & يزّوهشكران & 3. \\
\hline $\begin{array}{c}\text { Medicine, Research \& } \\
\text { Experimental; Pharmacology \& } \\
\text { Pharmacy }\end{array}$ & if & $\varepsilon / 4 \wedge$ & $\Delta q \mu$ & $\Delta V \cdot$ & $\wedge \Lambda$ & علوم و تحقيقات تهران & كاظه يريور & 1 \\
\hline Hematology & r & $1 \cdot / 9$ & $1 \wedge 9$ & $9 \cdot 0$ & $\wedge$ & علوم و تحقيقات تهران & مهرداد هاشمى & r \\
\hline Neurosciences & IV & $9 / \Delta 9$ & 411 & マ^८ & Ar & علوم يزشكى تهران & محمد ناصحى & r \\
\hline $\begin{array}{c}\text { Dentistry, Oral Surgery \& } \\
\text { Medicine }\end{array}$ & 9 & $F / V V$ & trt & $r \cdot \Delta$ & st & دندانيزشكى تهران & وحيد رخشا & r \\
\hline Genetics \& Heredity & $\wedge$ & $r / \Delta \varphi$ & 10 . & 109 & gr & 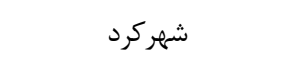 & عباس دوستى & $\Delta$ \\
\hline $\begin{array}{l}\text { Biotechnology \& Applied } \\
\text { Microbiology }\end{array}$ & Ir & $V / \& V$ & 411 & ret & $\Delta \Lambda$ & 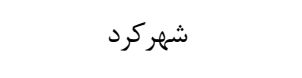 & ابراهيم رحيمى & 4 \\
\hline Chemistry, Medicinal & 9 & $r / 9 \Lambda$ & 199 & rl. & $\Delta V$ & علوم و تحقيقات تهران & يريجهره يغمايى & $\checkmark$ \\
\hline Chemistry, Medicinal & 14 & س & $v F$. & VFa & $\Delta r$ & علوم و تحقيقات تهران & اكرم عيدى & $\wedge$ \\
\hline Medicine, General \& Internal & 19 & $I T / A \Lambda$ & 4.1 & 911 & is & علوم و تحقيقات تهران & شهربانو عريان & 9 \\
\hline Chemistry, Medicinal & 11 & $1 \cdot 1 \cdot 1$ & FVD & FAF & is & علوم و تحقيقات تهران & عبدالحسين روستاييان & \\
\hline Emergency Medicine & 10 & $14 / 91$ & 99. & GVI & iq & علوم يزشكى تهران & محمدحسين كلانترمعتمدى & 1 . \\
\hline
\end{tabular}

اجايندكس 19 محمدحسين كلانترمعتمدى كه اج ايندكس ها را دارا هستند، به معناى تاثير گذارى بيشتر اين يزوهشگران در اين حوزه موضوعى است.

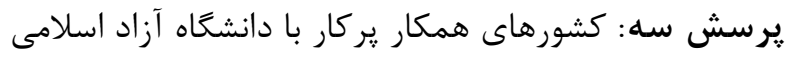

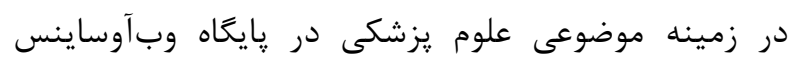

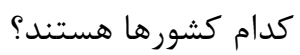
مشاركت در انجام يزوهش، شراكت و تسهيم دانش، مهارتها و فنون و ايجاد شبكهاى از روابط علمى ميان دانشمندان

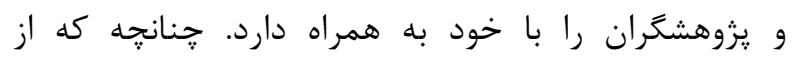

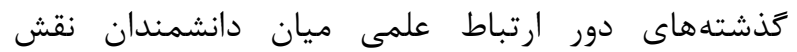
جشمخيرى در ييشرفت علم داشته است. در ادامه نمودار r بخش كوجكى (• •ا رتبه برتر) از مشاركت و همكارى ديخر

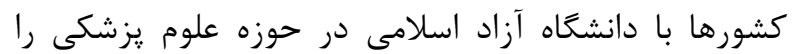
نمايش مى دهد. نمودار r نشانگر اين است كه كشور آمريكا با عیى ركورد علمى در رتبه اول كشورهاى همكار علمى با دانشعاه آزاد اسلامى در زمينه علوم يزشكى قرار دارد و كشور مالزى با

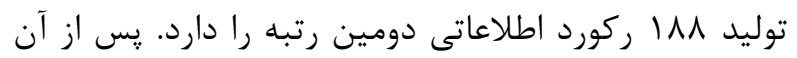

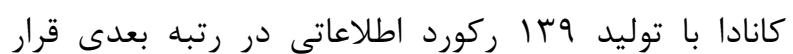
كرفته است.
توليدات علمى يزوهشگَان دانشگاه آزاد اسلامى در حوزه موضوعى علوم يزشكى تهيه شد. قابل ذكر است، جهت تروته كزينش دقيقتر يروهشگران برتر دانشعاه آزاد اسلامى در زمينه علوم يزشكى، ملاكى انتخاب هيات علمى بودن در

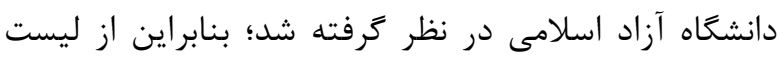

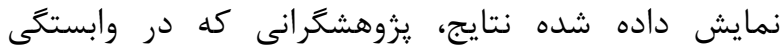
سازمانى دانشگاه آزاد اسلامى ذكر نشده بود از ليست حذف دهاه شدند. بر اساس دادههاى به دست آمده در جدول ا، كاظم يريور

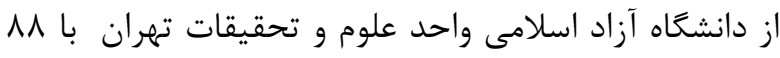

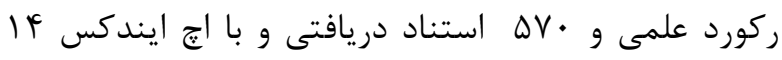
رتبه اول را از دانشگاه آزاد اسلامى در حوزه علوم يزشكى كسب كرده است و مهرداد هاشمى از دانشعاه آزاد اسلامى

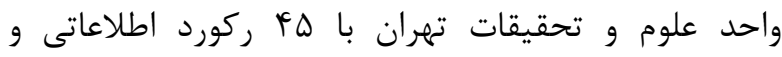

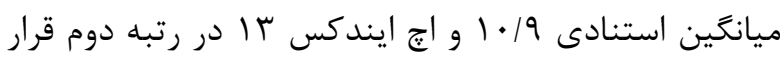
دارد. كه يس از آن، محمد ناصحى از دانشعاه آزاد اسلامى

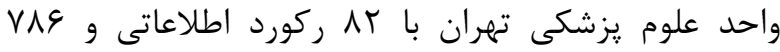

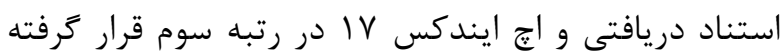

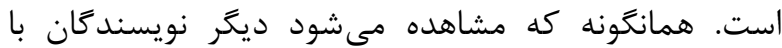
اختلاف ناجندان در رتبههاى بعدى قرار دارند. اما، با وجود رتبهبندىها محمد ناصحى كه در رتبه سوم قرار دارد اما

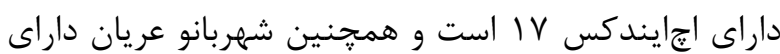


با نشر of Biotechnology رتبه اول را كسب كرده است. نشريه International Journal of Advanced Biotechnology and Research نشر rVT مقاله در رتبه دوم قرار گرفته است و نشريه African Journal of Microbiology Research نشر TrV Tr ركورد به عنوان سومين منابع هسته حوزه علوم

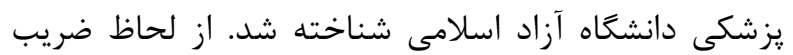

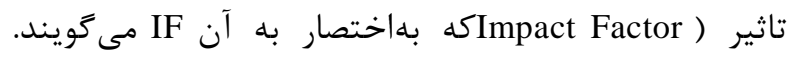
شاخصى كمّى است كه ميزان ارجاع با رفرنسدهى به به به به به

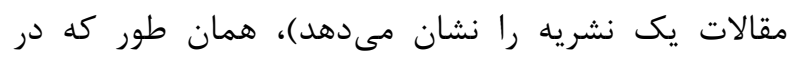

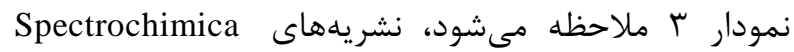
Acta Part A Molecular and Biomolecular Iranian Journal با ضريب تاثير Ir/9pectroscopy و/ADF بf Basic Medical Sciences Iranian Journal of Pharmaceutical Research تاثير س/1/1/ در رتبه هاى بعدى قرار گرفتند در صورتى كه داراى اعتبار يزوهشى هستند.

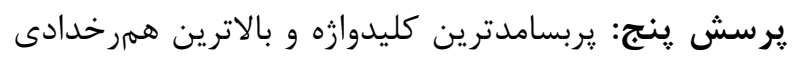
كليدوازهها در زمينه موضوعى علوم يزشكى ديس دانشعاه آزاد

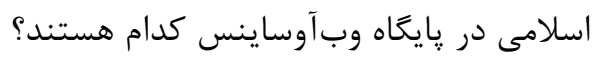

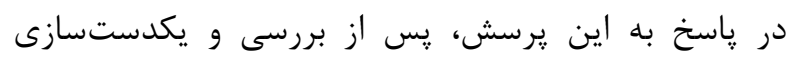

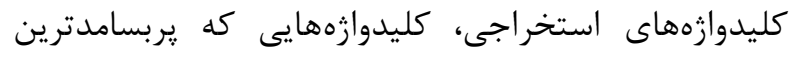

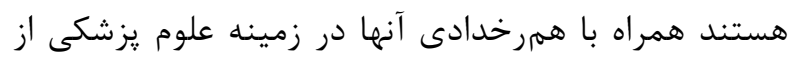

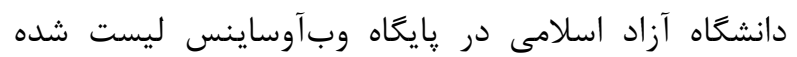

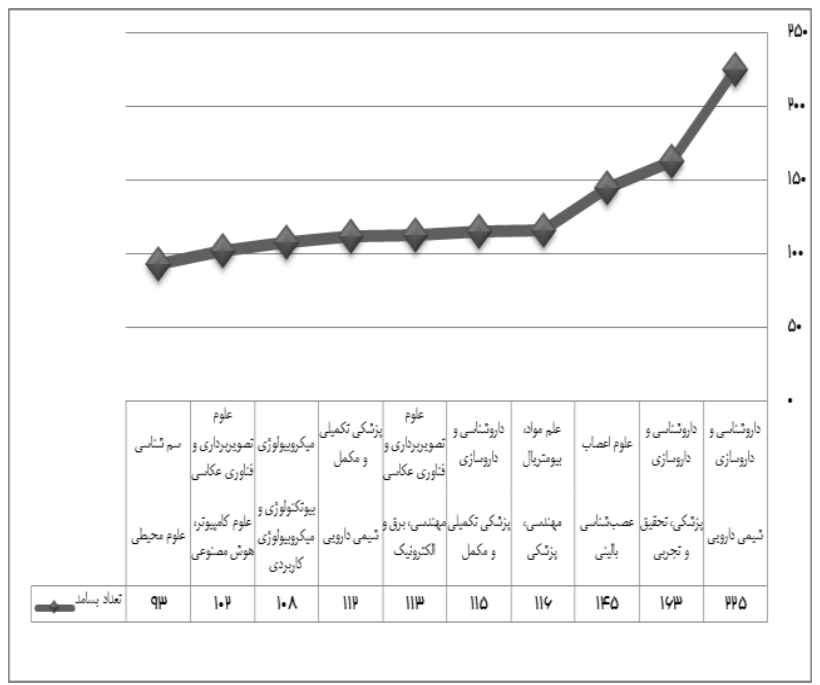

نمودار F. يربسامدترين كليدوازمهاى همرخداد در زمينه علوم يزشكى آمار

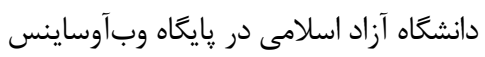

يرسش جهمار: منابع هسته در نشر يافتههاى علمى يزوهشگران دانشگاه آزاد اسلامى در زمينه علوم يزشكى در يايعاه وبآوساينس كدامند؟

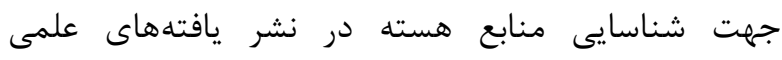

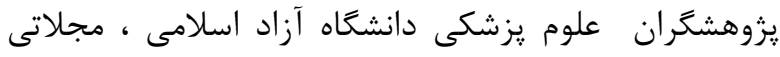
كه بيشترين سهم در نشر توليدات علمى دانشعاه آزاد

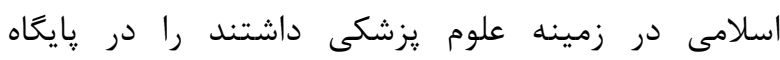
وبآوساينس استخراج و در نمودار ب ترسيم شد.

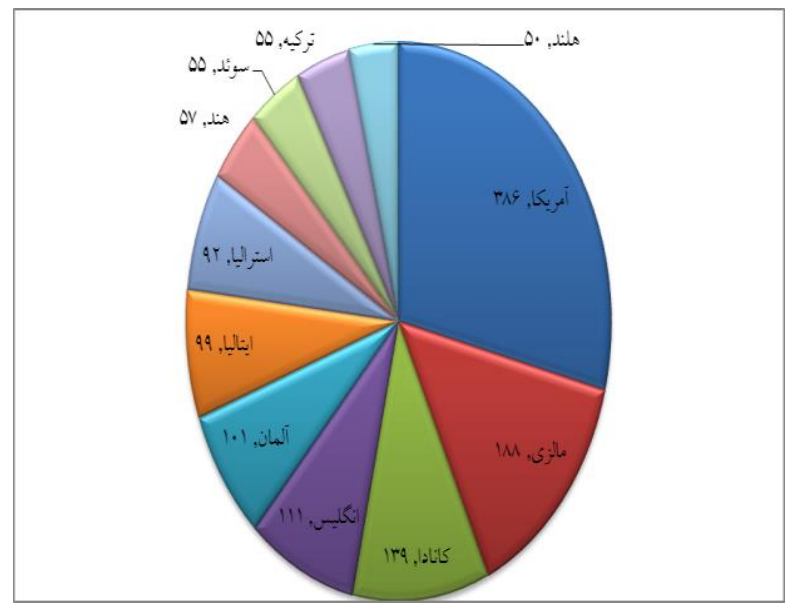

نمودار r. كشورهاى يركار و همكار با دانشعاه آزاد اسلامى در زمينه موضوعى علوم يزشكى در يايگاه وبآوساينس

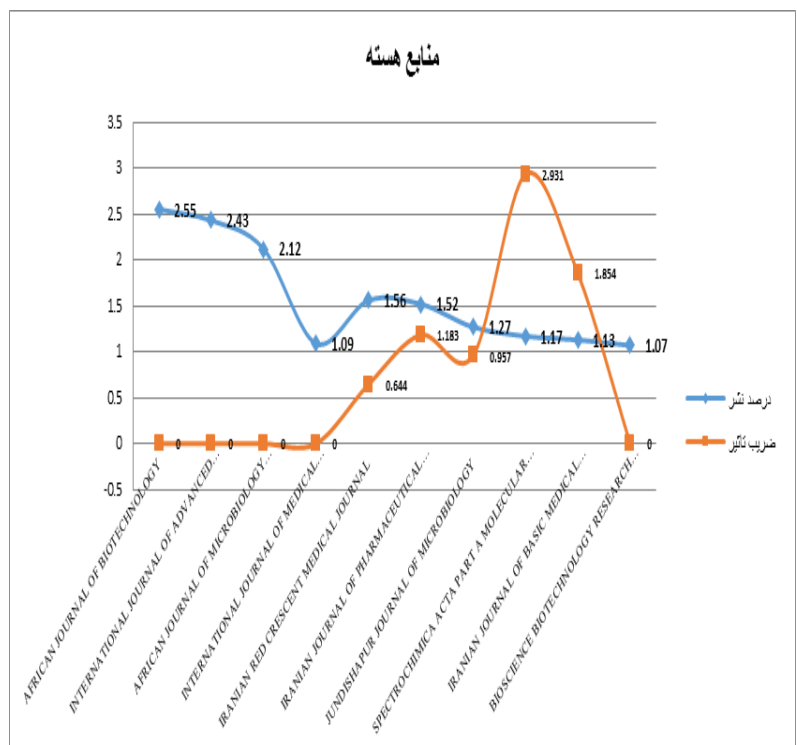

نمودار آ. منابع هسته در نشر يافتههاى علمى يزوهشگران دانشگاه آزاد

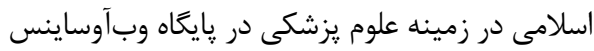

يافتههاى نمودارץ نشان مىدهد كه اغلب مقالات علمى حوزه موضوعى علوم يزشكى دانشگاه آزاد اسلامى در درى African Journal نشريه هاى فوق انتشار يافتند كه نشريه 


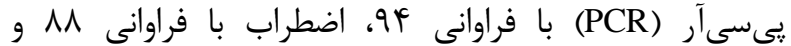
افسردگى با فراوانى NV يربسامدترين كليدوازهها در زمينه

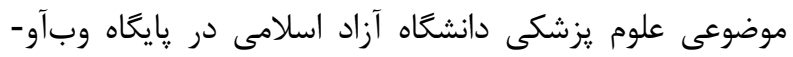
ساينس هستند. يرسش شش: ركوردهاى علمى نمايه شده حوزه علوم يزشكى

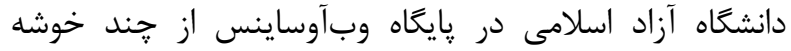
تشكيل شده است و هر خوشه شامل جه كليدوازههاى است؟ آنا

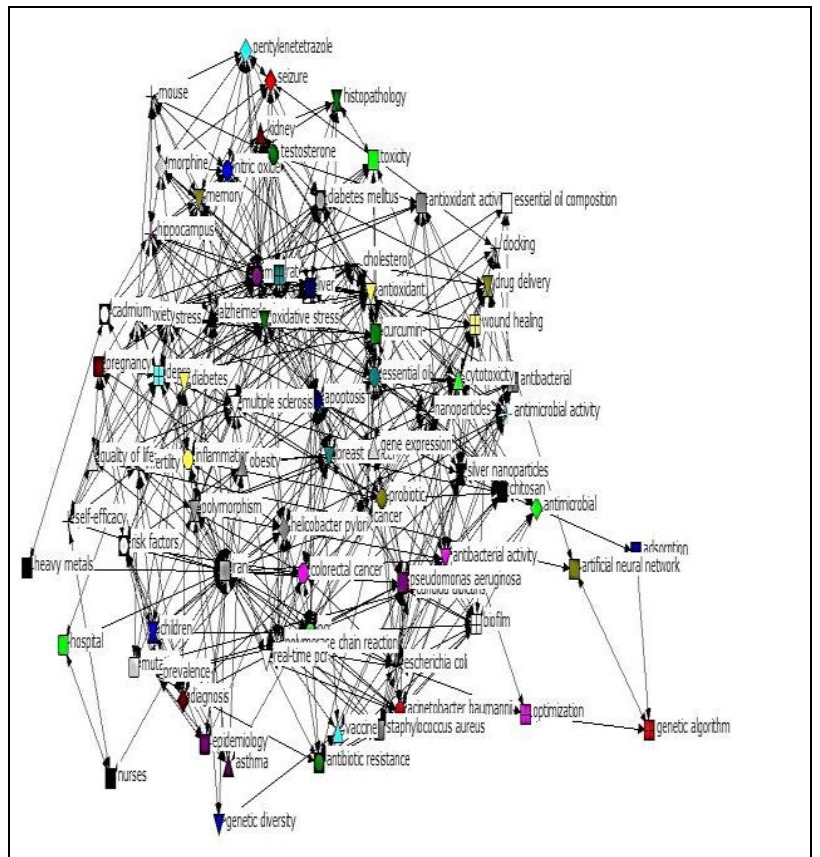

شكلا. شبكه كليدوازههاى توليدات علمى دانشكاه آزاد اسلامى در

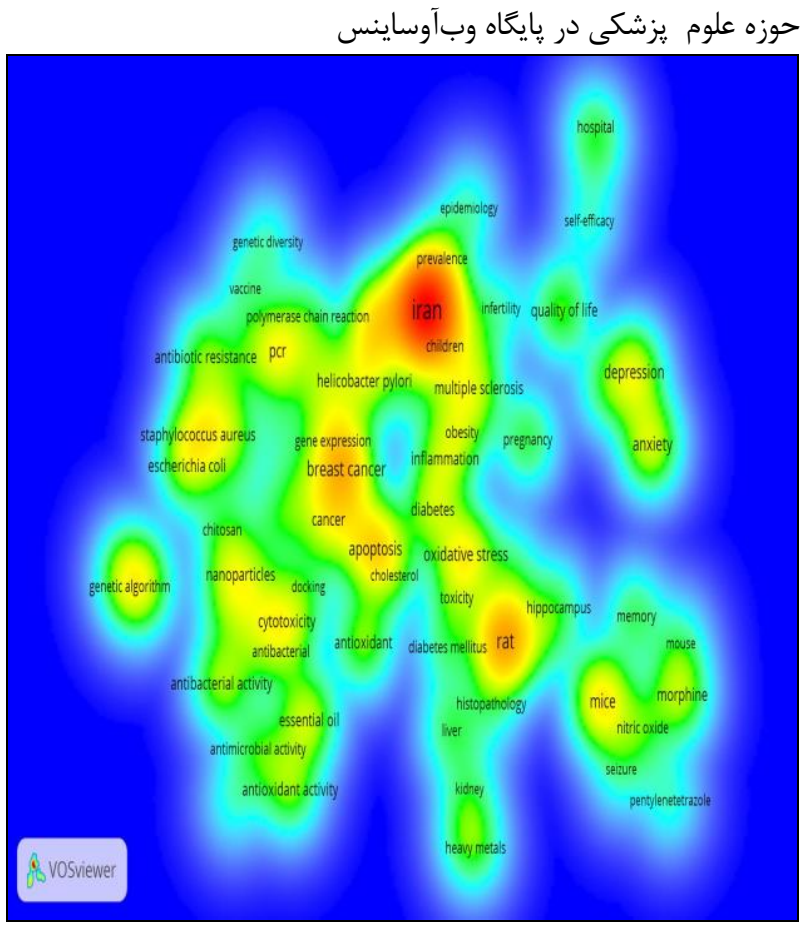

شكل r. نقشه קֶَالى موضوعى توليدات علمى دانشكاه آزاد اسلامى

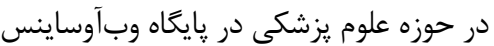

اطلاعات نمودار ₹ نشانكر يربسامدترين كليدوازههاى همرخداد در زمينه علوم يزشكى دانشكاه آزاد اسلامى در يايكاه وبآوساينس است كه بيشترين بسامد همرخدادى بين كليدوازههاى "شيمى دائى

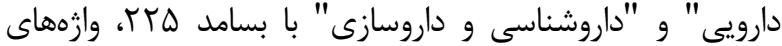
"يزشكى، تحقيق و تجربى" و "داروشناسى و داروسازى" با بسامد دارساي

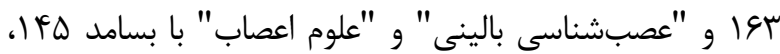

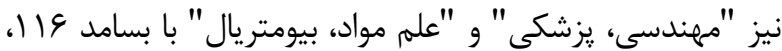
"يزشكى تكميلى و مكمل" و "داروشناسى و داروسازى" بـ با بسامد برد

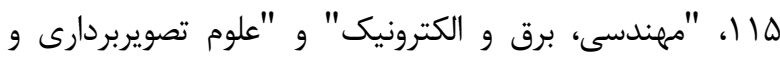
فناورى عكاسى" با بسامد سرا، "شيمى دارويى" و و "يزشكى

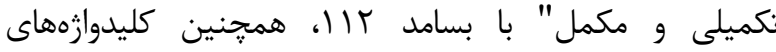
"بيوتكنولوزى و ميكروبيولوزى كاربردى" و "ميكروبيولوزى" با بالي

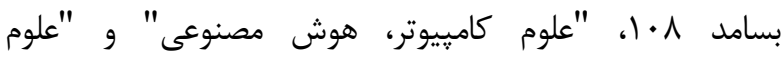

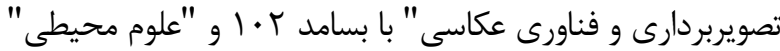
و "سم شناسى" با بسامد سو است. با بررسى كليدوازهها،

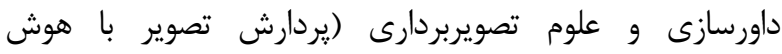
مصنوعى) جهت درمان و تشخيص بيمارىها بيشتر موضوعات

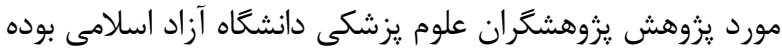
است. همجنين در ادامه كليدوازمهاى يربسامد در زمينه موضوعى براني

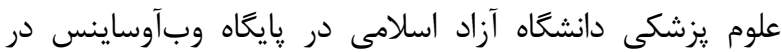
نمودار ل ه نمايش داده شده است.

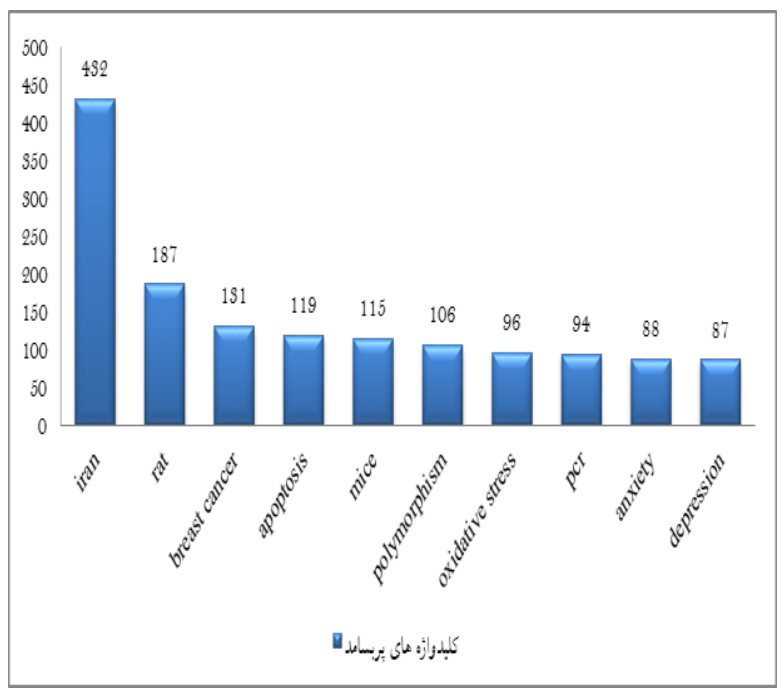

نمودارها. كليدوازههاى يربسامد در زمينه موضوعى علوم يزشكى برانى دانشخاه آزاد اسلامى در بايكاه وبآوساينس

در نمودار ه مشاهده مىشود كه كليدوازههاى ايران با فراوانى TrF، موش با فراوانى INV

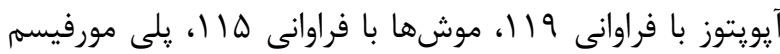

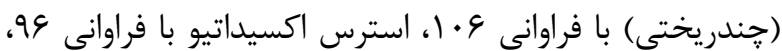



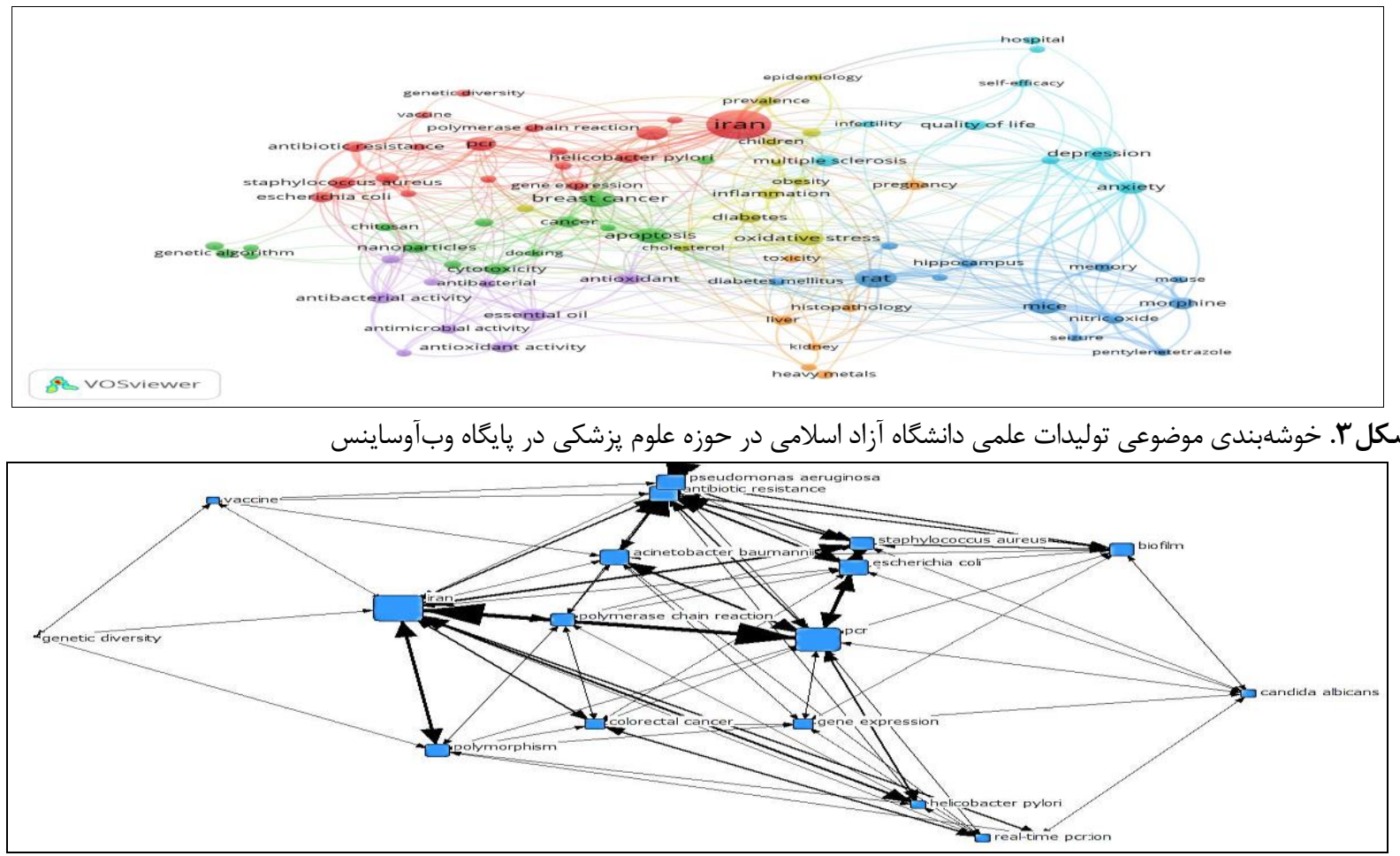

شكل F. خوشه شماره ا كليدوازههاى ركوردهاى علمى علوم يزشكى دانشكاه آزاد اسلامى در بايخاه وبآوساينس

در اين نقشه، كليدوازههاى كه بيشتر با يكديخر در ارتباط

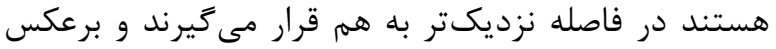

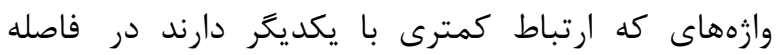

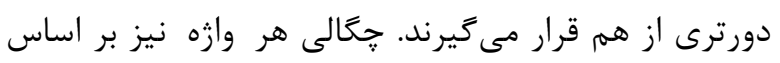

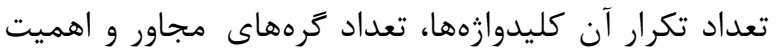
كرههاى مجاور تعيين مىشود. در اين نقشه، كليدوازههاى

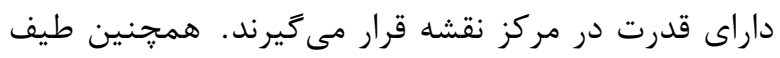

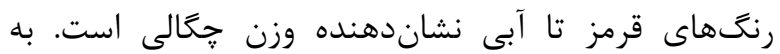

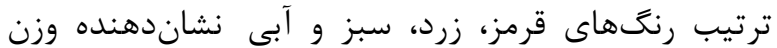

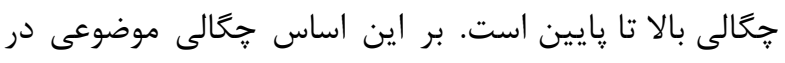

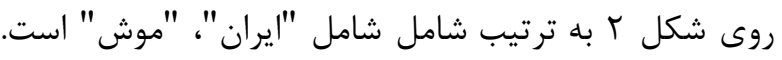
همجنين خوشهبندى موضوعى توليدات علمى دانشعاه آزاد

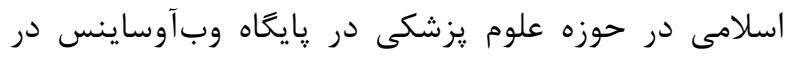
شكل إر ائه شده است. جنان كه در شكل r مشخص است دايرهها كه هركدام

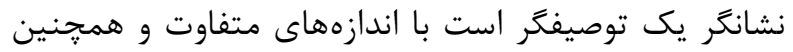
رنختهاى مختلفى، ديده مىشود. هر كدام از دايرهها (كره)

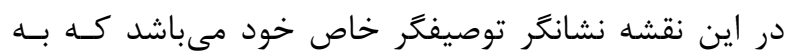
عنوان برجسب مشخص شده و خطوط نشاندهنده رابطه

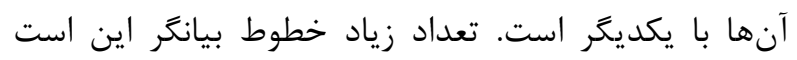

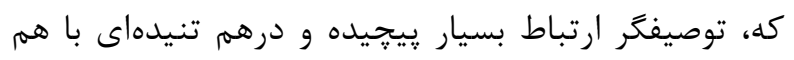

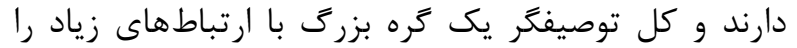

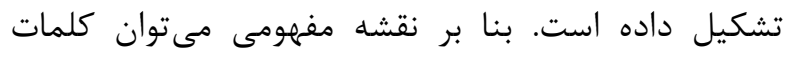

خوشهبندى، يك فعّاليت توصيفى است كه شناسايى و

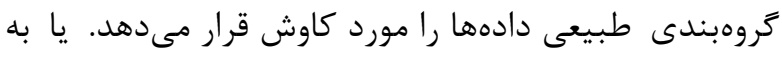

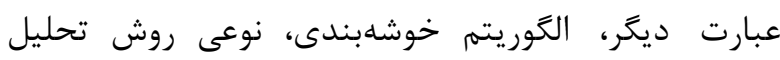
دادهها است كه مىتواند مجموعه دادهها را در خروههايى طبقهبندى شده بر اساس معيارهاى گروهى تنظيم كند. نيز

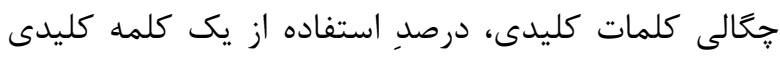
يا عبارت كليدى به نسبت تعداد كل كلمات محتواى يك صفحه است. در ادامه نقشه علمى موضوع علوم يزشكى

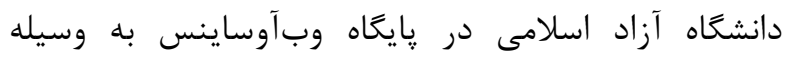
خوشهبندى و جحكالى موضوعات ترسيم شده است. در شكل 1 شبكه كليدوازههاى توليدات علمى دانشعاه آزاد اسلامى در حوزه علوم يزشكى در پايگاه وبآوساينس

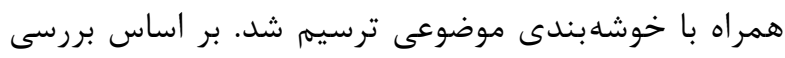

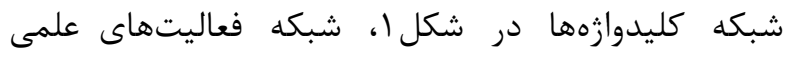

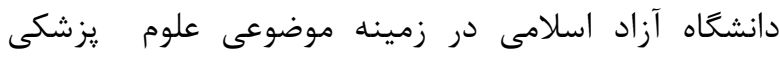

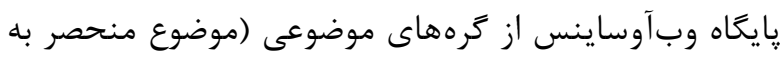
فرد) و يِيوندهاى مختلفى (همر رخدادى كليدوازهها) تشكيل

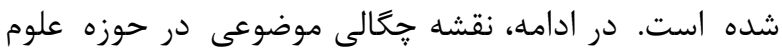

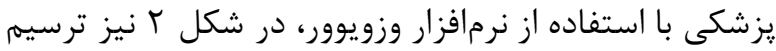

$$
\text { و تحليل مىشود. }
$$


"استرس اكسيداتيو" همجِين "شيوع" و "عوامل خطر"

است.

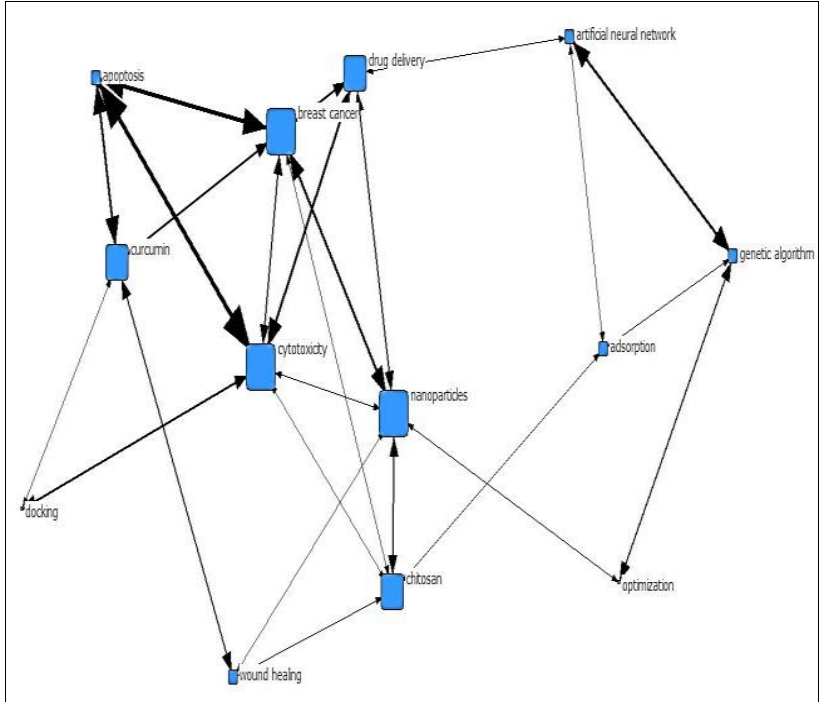

شكله. خوشه ب كليدوازههاى ركوردهاى علمى علوم يزشكى دانشكاه

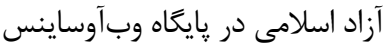

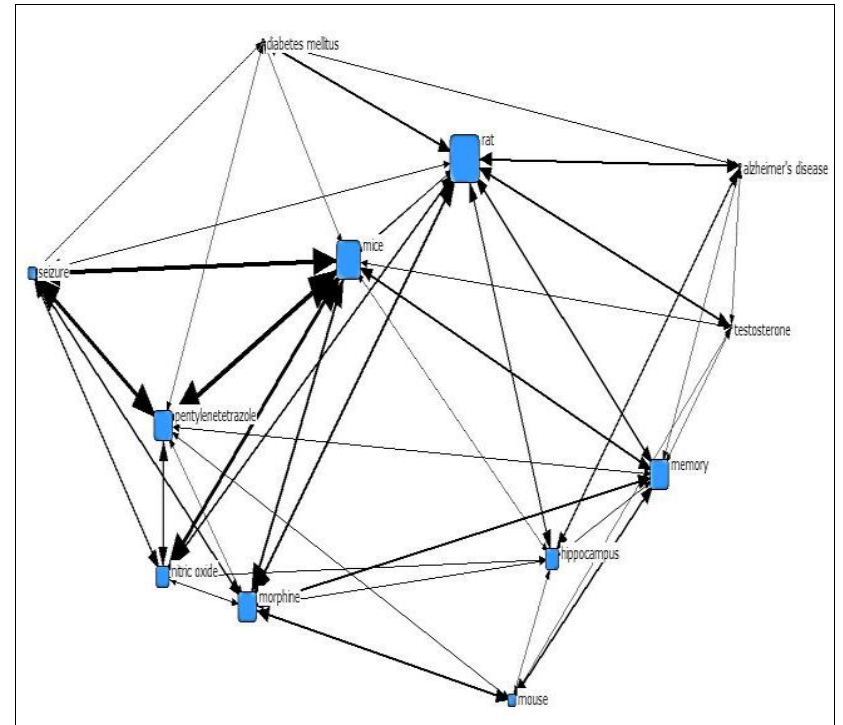

شكل و. خوشه ب كليدوازههاى ركوردهاى علمى علوم يزشكى دانشكاه آزاد اسلامى در پايكاه وبآوساينس

شكل ^ م بيانكَ خوشه ه علوم يزشكى دانشكاه آزاد اسلامى

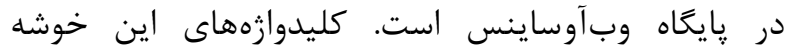

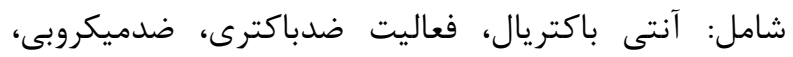
فعاليت ضدميكروبى، آنتىاكسيدان، فعاليت آنتى اكسيدانى، روغن اسانس، تركيب اسانس و نانوذرات نقره است. اما

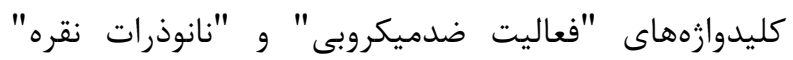
بيشترين همرخدادى را در اين خوشه موضوعى دارند.
استفاده شده در عنوان و جكيده توليدات علمى در زمينه

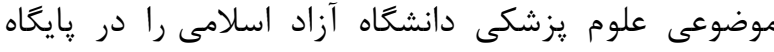
استنادى وبآوساينس مشاهده كرد. در ادامه، در شكلهاى f الى · الهر يك از خوشهها و نيز ارتباط بين كليدوازه هاى هر خوشه به تفكيك در قالب تصاوير ارائه شده است.

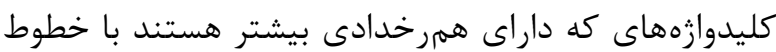
ير رنخَ مشخص شده است.

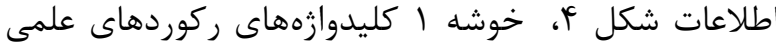

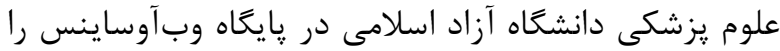
نشان مىدهد. اين خوشه از 11 كليدوازه آسينتوباكتر بائومانى، مقاومت به آنتى بيوتيك، بيوفيلم، كانديدا

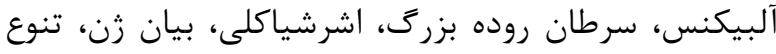

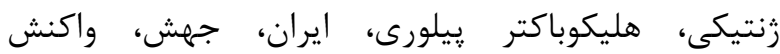

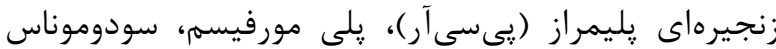
آئروزينوزا، زمان واقعى يى سيى آر، استافيلوكوكوس اوريوس و واكسن تشكيل شده است و بيشترين همرخدادى را بين

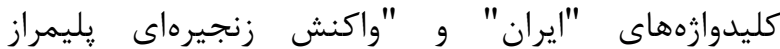

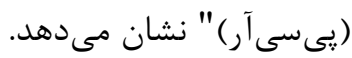

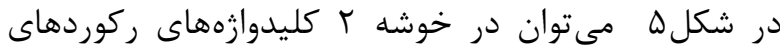
علمى علوم يزشكى دانشعاه آزاد اسلامى در بايخاه وبآه

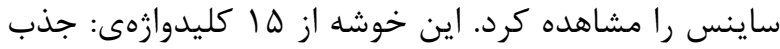
سطح، آيويتوز، شبكه عصبى مصنوعى، سرطان يُّتان،

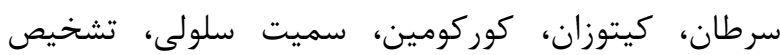

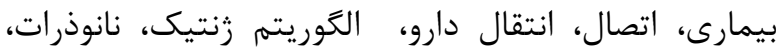
بهينه سازى و درمان زخم تشكيل شده است. بيشترين

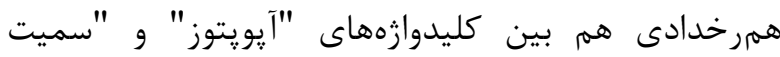

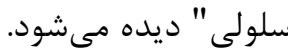
همانطور كه در شكل \& قابل مشاهده است، در خوشه

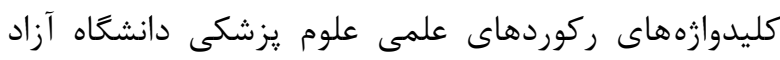

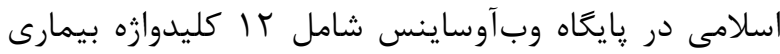
آلزايمر، ديابت قندى، هييوكامب، حافظه، موش، مورفين،

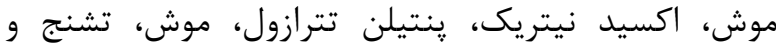

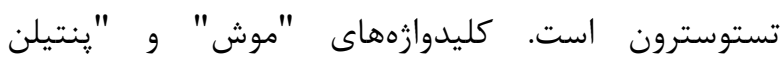
تترازول " بيشترين همرخدادى را دارند. ترسيم شكل V بر مبناى خوشه F كليدوازههاى ركوردهاى

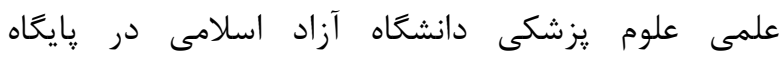

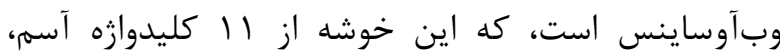
كودكان، كلسترول، ديابت، إيبدميولوزى، التهاب، جاقى، استرس اكسيداتيو، شيوع، يروبيوتيك و عوامل خطر شكل

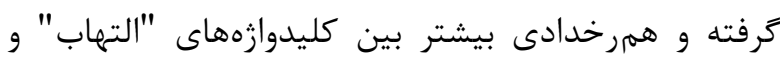




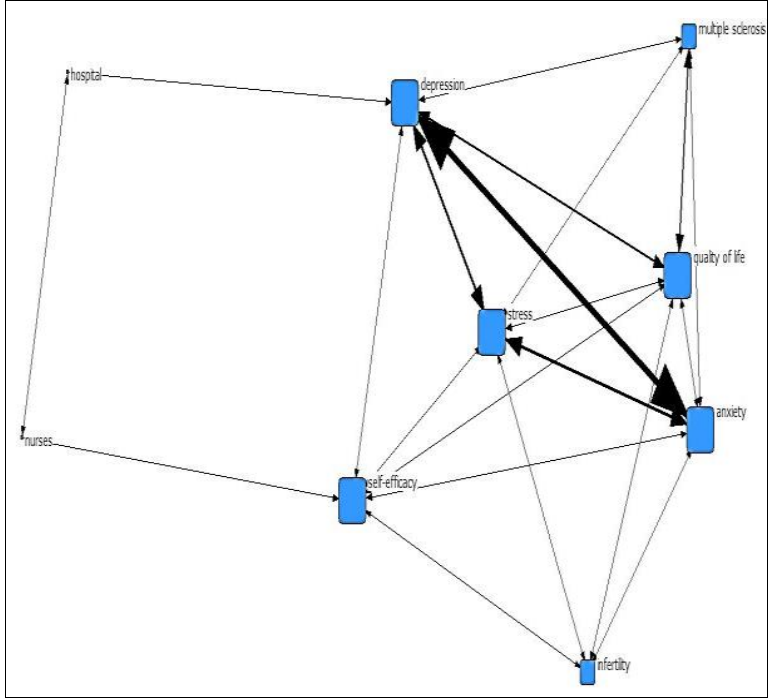

شكل9. خوشه 9 علوم يزشكى دانشعاه آزاد اسلامى در پايكاه وبآوساينس

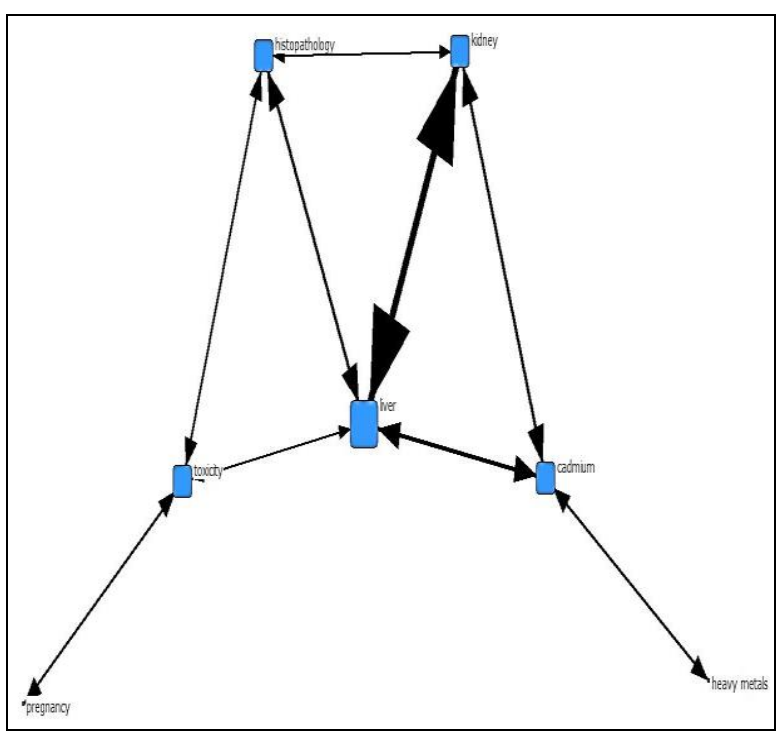

شكل +1. خوشه V علوم يزشكى دانشعاه آزاد اسلامى در پايگًاه وبآو-

ساينس

بحث سرمايه كذارى مادى و معنوى در يك حوزه موضوعى علاوه بر

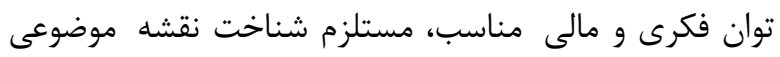

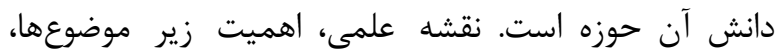

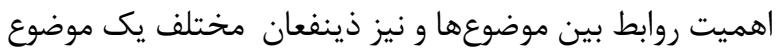
را مشخص مى كند و ديدى همه جانبه به نويسند أنان آن حوزه، يزوهشگران، و سازمانهاى يزوهشى خواهد داد، و بدين ترتيب دانشعاهها مىتوانند رويكردى جامع، براى تعريف و تبيين طرحهاى يزوهشى كاربردى داشته باشند و از يزوهشهاى

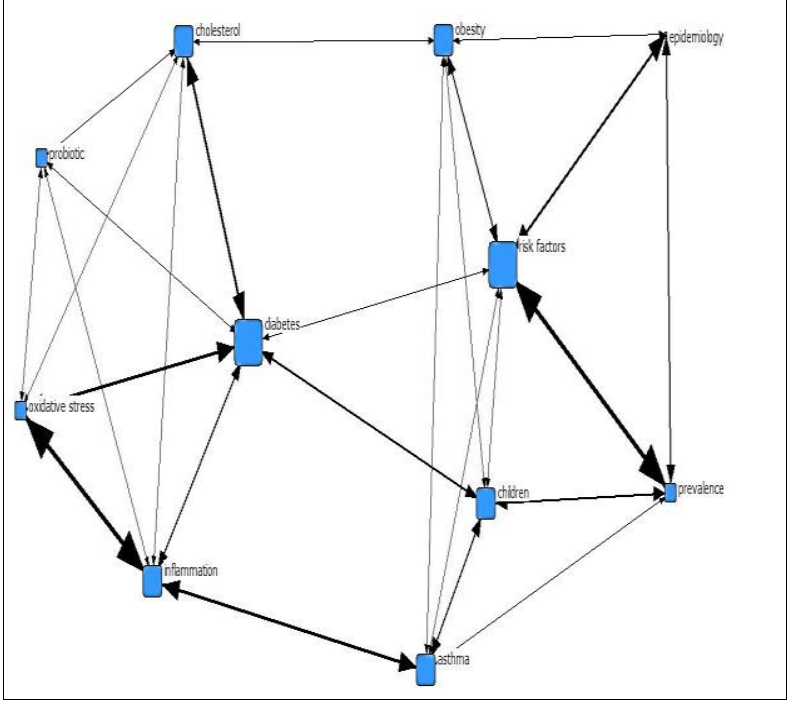

شكل V. خوشه F كليدوازمهاى ركوردهاى علمى علوم يزشكى دانشگاه آزاد اسلامى در پايگاه وبآوساينس

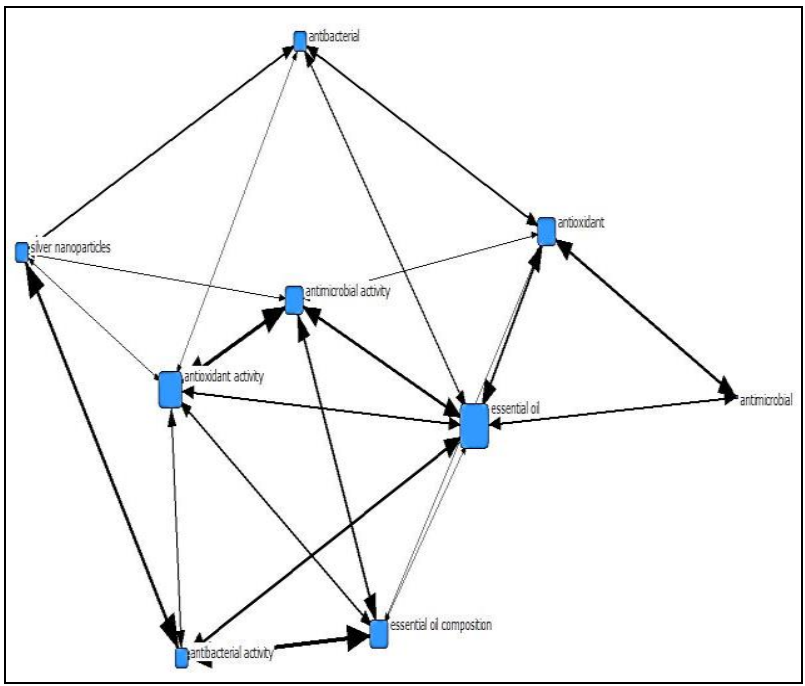

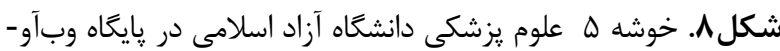
ساينس با شكل 9 خوشه 9 علوم :زشكى دانشعاه آزاد اسلامى در يايگاه وبآوساينس قابل ملاحظه است. 9 وكليدوازه اضطراب، افسردگى، بيمارستان، نابارورى، مولتييل

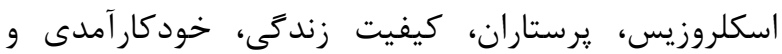
استرس تشكيلدهنده خوشه ع هستبند. كليدوازههاى

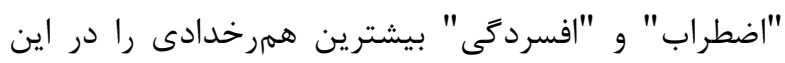
خوشه موضوعى دارند. در شكل • ا خوشه V علوم يزشكى دانشعاه آزاد اسلامى در קايخاه وبآوساينس ترسيم شده است. V كليدوازه اين خوشه عبارت از كادميوم، فلزات سنخين، هيستوياتولورَى، كليه، كبد، باردارى و و سميت هستند كه بيشتروين همر خدادى را كليدوازههاى "كليه" و "كبد" دارند. 


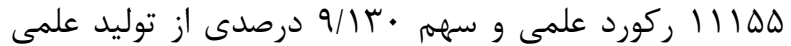

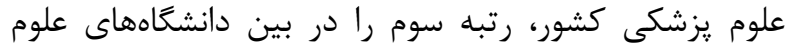

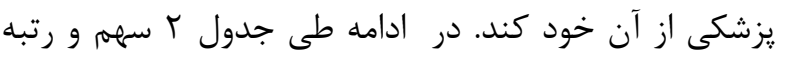
دانشكاه آزاد اسلامى در توليدات علمى علوم يزشكى در سطح ملى و بينالمللى به تصوير كشيده شده است.

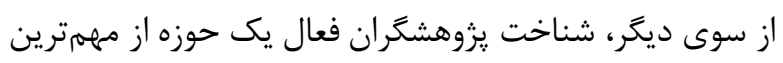

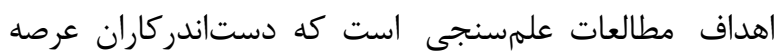
يزوهش را در هدف كذارىهاى حمايتى و تشكيل تيمهاى

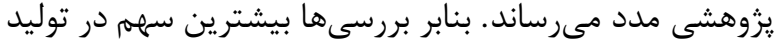

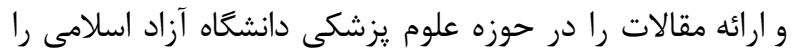
كاظم يريور از دانشكاه آزاد اسلامى واحد علوم و و تحقيقات

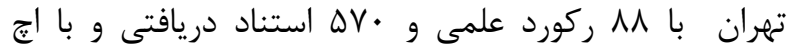

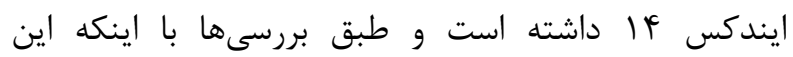
يزوهشكر متخصص در زيستشناسى سلولى تكوينى هستند،

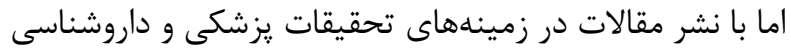

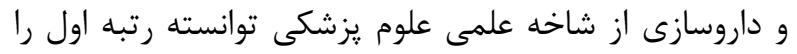

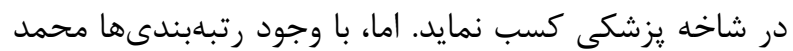

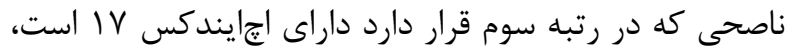

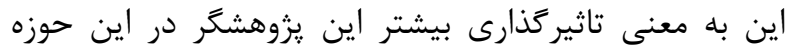

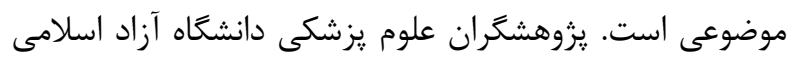
علاوه بر تلاش در توليد علم در سطح بينالمللى، در استناد هم دستى يرتلاش داشتهاند. زيرا كه تعداد استنادها از

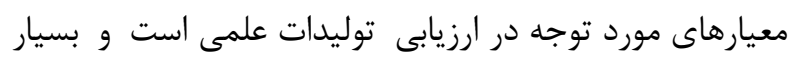

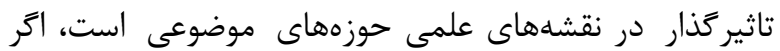
تعداد استنادهاى يكى مدرك، كمتر از ميزان آستانه تعيين شده

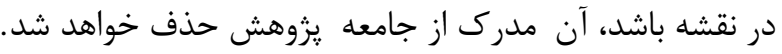

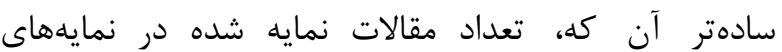
بينالمللى بيانكر رشد كمّى توليدات علمى و ميزان استنادات

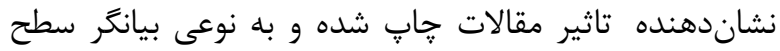

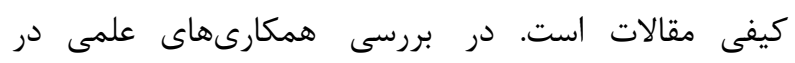

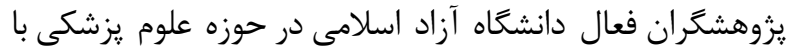
ديخر كشورها، آمريكا از لحاظ همكارى با دانشخاه آزاد اسلامى آنى

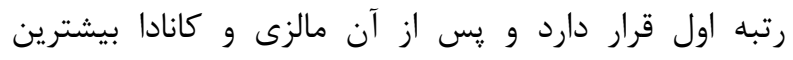
همكارى علمى را داشتهاند، كه اين نشان از استقبال كشورهاى إن

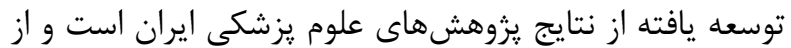

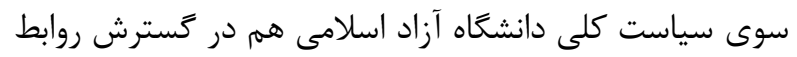
بينالملل موثر بوده، كه با دانشكاههاى معتبر دنيا قرارداد ادراد همكارى علمى و آموزشى را منعقد كرده است. با اينكه

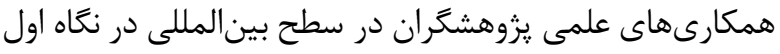

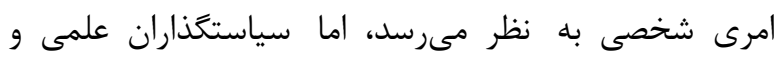

صورت كرفته براى شناخت ابعاد مختلف يك موضوع استفاده

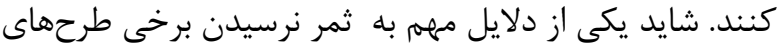

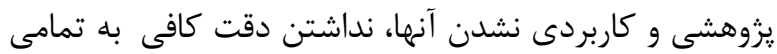
ابعاد يك مسئله باشد. به نظر مىرسد تبيين نقشه موضوعى اندي بتواند ديدى جامع و دقيق نسبت به حوزههاى علمى و اهميت موضوعات در طى ساليان را فراهم كند. بهعلاوه، تجزيه و تحليل نقشه علمى يك حوزه از دانش، به نوعى اصطلاحنامه موضوعى آنى

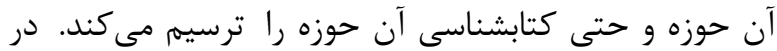

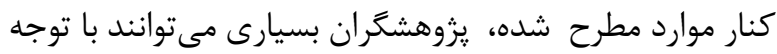
به ابعاد مختلف نقشه موضوعى دانش، به تعريف طرحهاى يزوهشى و بررسى بومى آن موضوع بيردازند.

جدولrا. مقايسه توليدات علمى در همه حوزههاى علوم يزشكى باينًاه

\begin{tabular}{|c|c|c|c|}
\hline & & \multicolumn{2}{|c|}{ وبآوساينس در سطح ملى و بينالمللى } \\
\hline رتبه & رصد سهمه توليد علمى & تعداد توليد علمى & سطح جغرافيايى \\
\hline- & $1 \cdots$ & $r r, q \wedge V, \cdot \cdot \varphi$ & \\
\hline r. & $\cdot|Q|$. & $\|V, r\| r$ & \\
\hline r & $9 / 1 \%$. & $11,1 \Delta \Delta$ & نيكاه آزاد اسلامى \\
\hline
\end{tabular}

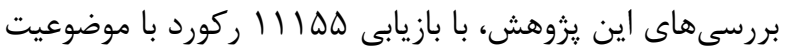

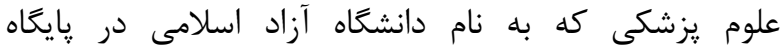

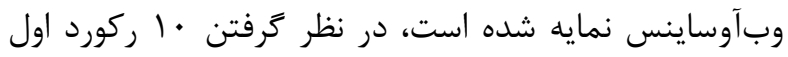
در هر مولفه، نشان مىدهد كه اولين نشر دانشحاه آزاد اسلامى آنى در حوزه علوم يزشكى در يايكاه وبآوساينس به سال 1999 با 1 ركورد اطلاعاتى برمى سالهاى مختلف رو به رشد بوده است كه بيشترين توليد علمى علوم يزشكى دانشكاه آزاد اسلامى در سطح بين المللى

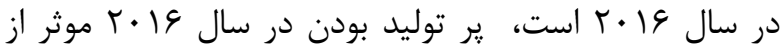
برجام و قوت گرفتن روابط بينالمللى دانست همجنين،

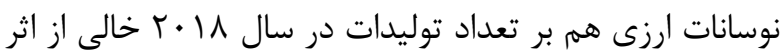

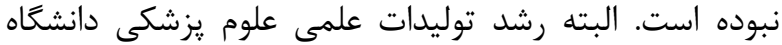

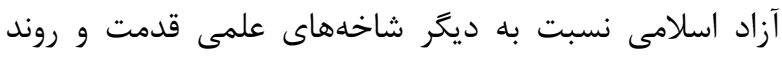
خوبى داشته و حضور علمى دانشخاه آزاد اسلامى در توليد علم كشورى اين حوزه موضوعى مشهود است و به عنوان شاهد اين

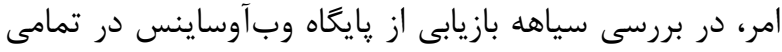

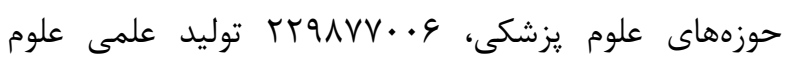

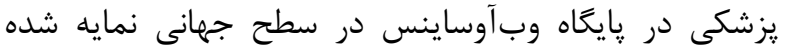

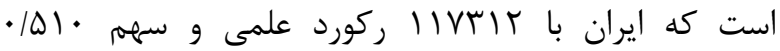
درصدى توانسته رتبه سىام را در سطح بينالمللى توليدات علمى علوم يزشكى كسب نمايد و دانشآ آزاد اسلامى هم باليا 
دريافت و همجنين، موضوعاتى را جهت اولويتهاى يزوهشى دئر

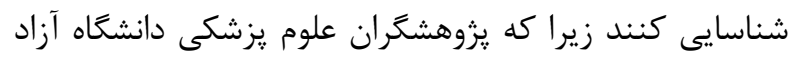

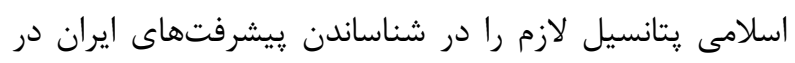
كنترل شيوع بيمارىهاى مسرى در سطح جهانى صرف نكردهاند. سنجش و ارزيابى علم واقعيتى است كه در كذشته و حال در درد

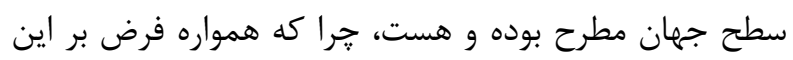

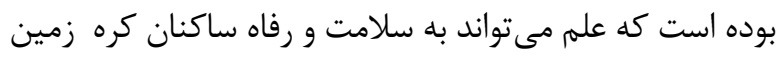

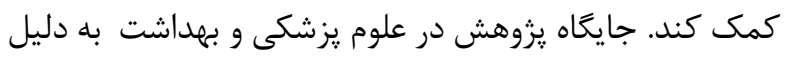

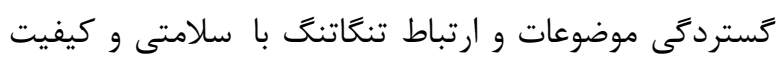

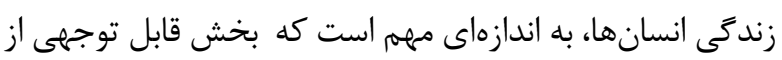

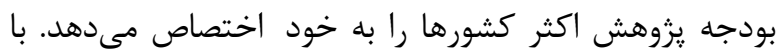

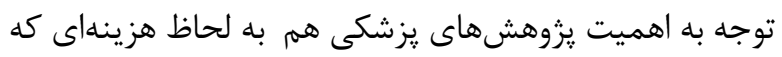

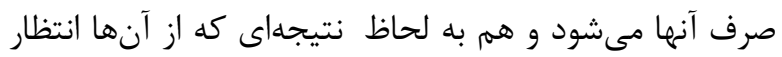
مىرود (يعنى كمك به بهبود شاخصهاى سلامت جامعه)،

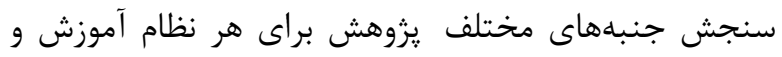

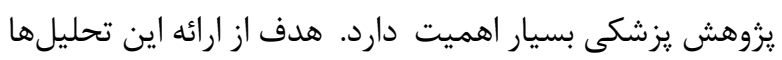

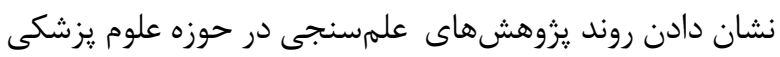

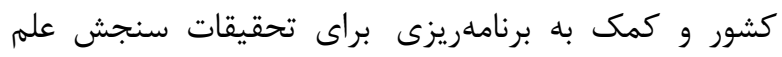

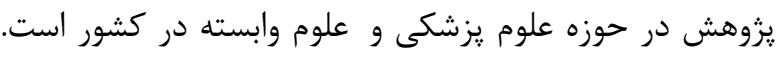

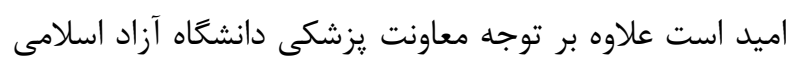

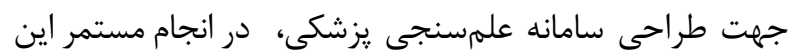

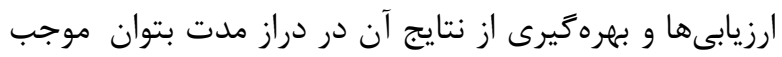

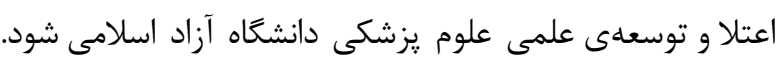
بىشك ارزيابى يزوهشهاى منتشر شده محققانى كه در حوزه

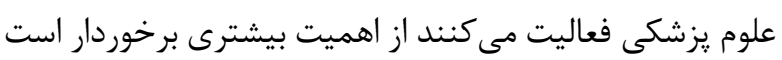

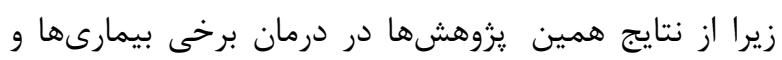

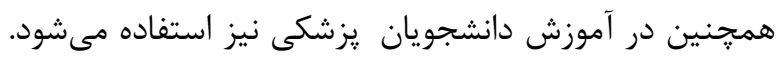

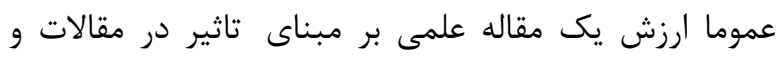

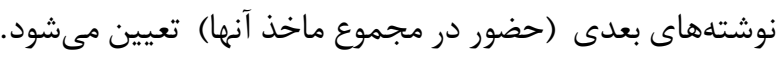

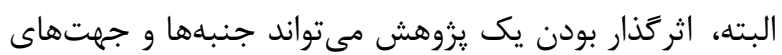

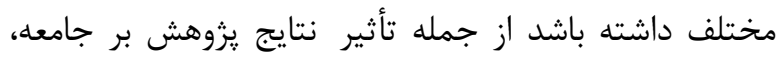

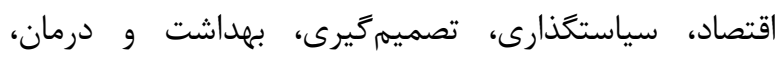

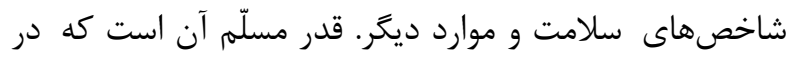

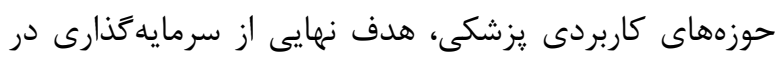
يزوهش، بهبود وضعيت بهداشتى و سلامت جامعه است. لذا

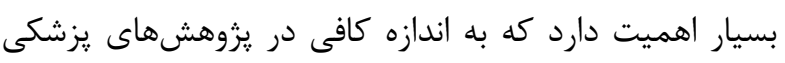

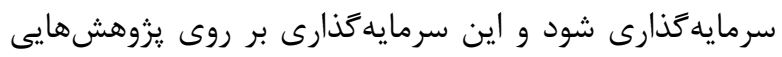

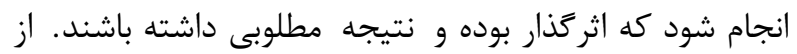
محدوديتهاى اين يزوهش مىتوان به محدود بودن امكانات
مسئولان دانشخاهها و مؤسسههاى يزوهشى كشور مىتوانند با

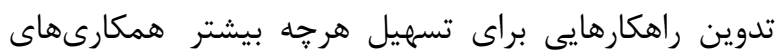

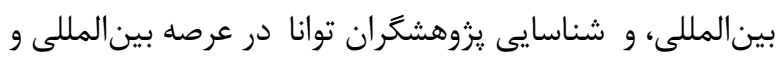

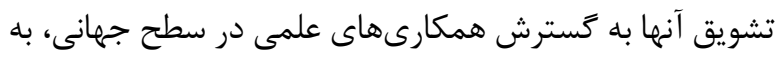

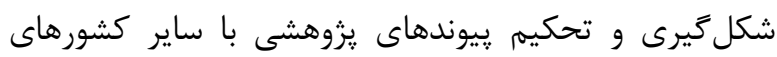

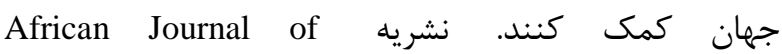
Biotechnology

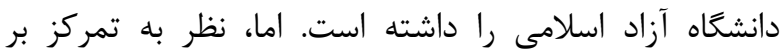

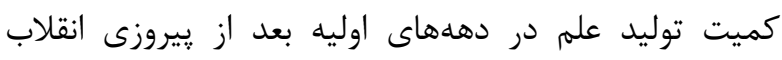

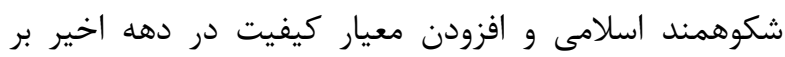

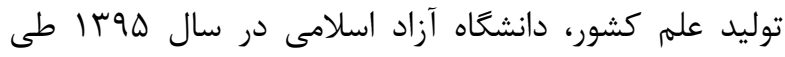

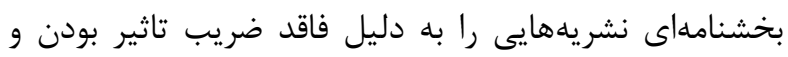

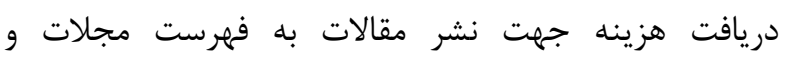
انتشارات جعلى و نامعتبر اعلام كرده است. همجنيني، نكته

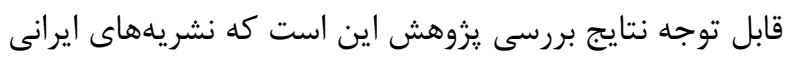

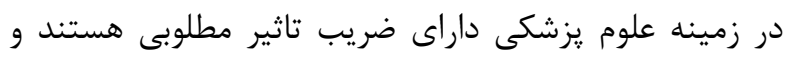

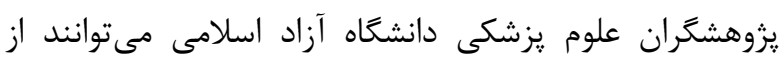
طريق نشريههاى داخلى در سطح بين المللى شناخته شوند.

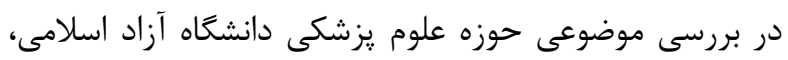

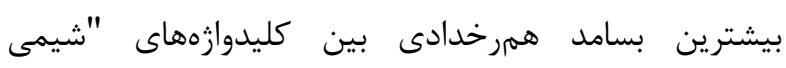

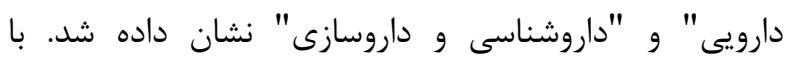
مشاهده بسامد كليدوازهها به صورت منفرد، مى توان عدم توجه

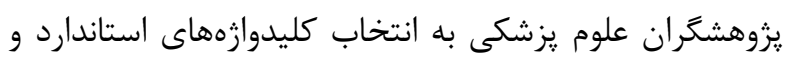

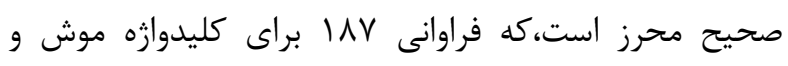

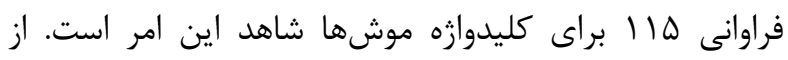

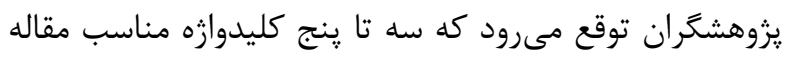

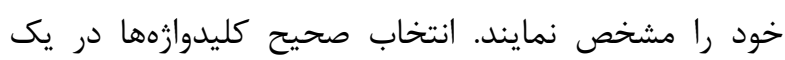

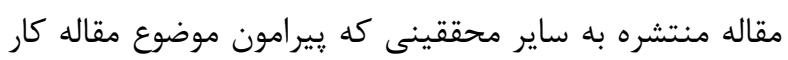

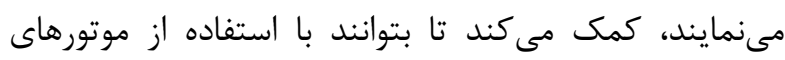
جستجو، به مقاله مورد نظر دسترسى يُ بيدا كنند. انتخاب

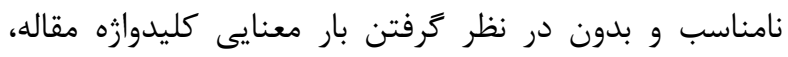

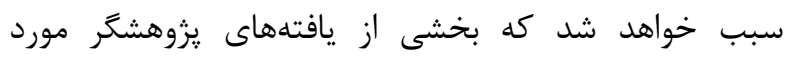

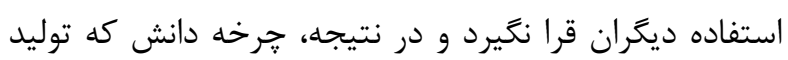

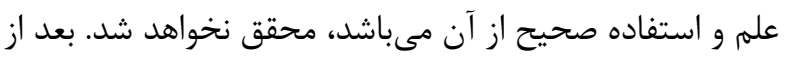

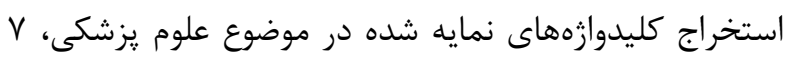
خوشه موضوعى قابل تفكيك است. اين خوشهها بيانكر اين

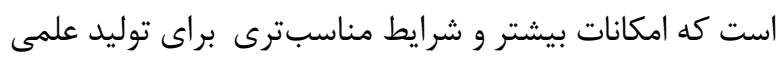

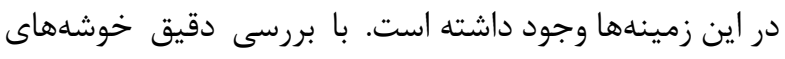

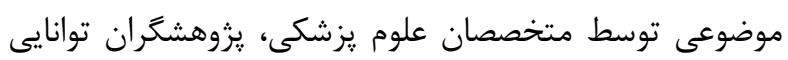

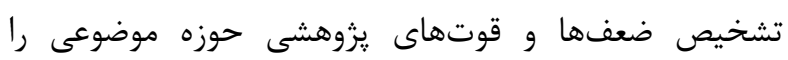


نمايد. همجنين، با توجه به اينكه يزوهشگران داراى شاخص هاى بالا نقش بسيار مهرى در كسترش و تكامل شبكههاى

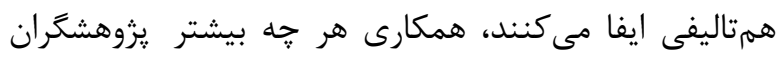
كليدى با يكديگر و جذب يروهشگران جوان مىتواند در رشد و يويايى هر جه بيشتر موثر باشد. مهمتر از همه، در وزرات بهداشت در كل و معاونت يزشكى دانشعاه آزاد اسلامى به به طور

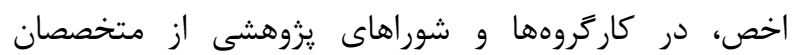
علمسنجى جهت مسيريابى صحيح توليد علم مدد جويند.

\section{تقدير و تشكر}

مقاله حاضر، از رساله دكترى با عنوان "ترسيم ساختار علمى

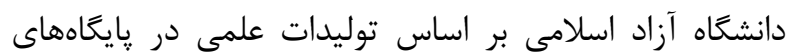

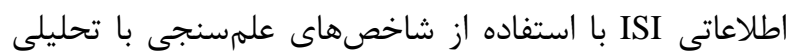
مبتنى بر آينده باوريذير" در دانشگاه آزاد واحد همدان استخرج شده است.
جستجو در زايعاه وبآوساينس، عدم آدرسدهى صحيح و

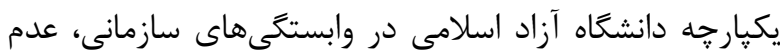
آشنايى يزوهشگران به كارگيرى كليدوازههاى استاندارد

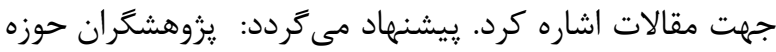
علوم يزشكى دانشعاه آزاد اسلامى با استفاده از خوشههاى

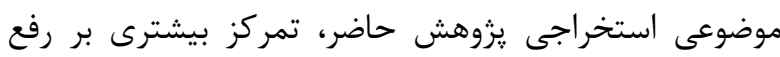

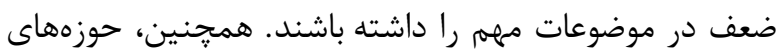
نوظهور شناسايى شده در اين يزوهش، توسط يزوهشگران حوزه علوم يزشكى دانشخاه آزاد اسلامى مورد بررسى قرار گيرند و

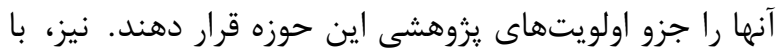
توجه به قابليتهاى مطالعات علمسنجى، انجام ساير فنون از قبيل تحليل استنادى، هم استنادى مدارك، هم استنادى

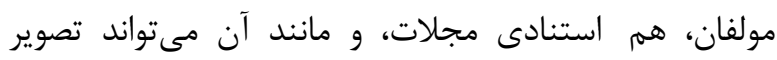

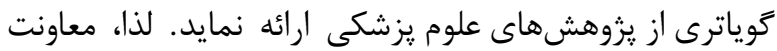

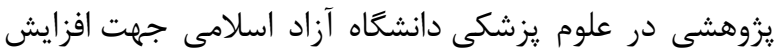

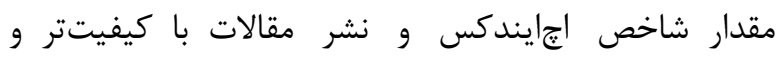
روزآمدتر، در تصويب موضوع طرحها دقت بيشترى را لحاظ

\section{REFERENCES}

1. Mirhosseini Z, Vahabi F. Investigating the scientific productions of iranian type pharmacy faculty members indexed in the institute for scientific information (ISI). Health Inf Manage 2011; 8:363-72. [In Persian]

2. Van Raan AF. Advanced bibliometric methods to assess research performance and scientific development: basic principles and recent practical applications. Res Evalu 1993; 3: 151-66.

3. Doucette L. A Review of Citation Analysis Methodologies for Collection Management. College Res Lib 2012; 73: 321-35.

4. Jamali HR, Asadi S. Shahram S. Editors. Impact assessment of medical research models and research. Tehran: The Academy of Medical Sciences, Islamic Republic of Iran; 2013. [In Persian]

5. Attar A, Shahbahrami A, Rad RM. Image quality assessment using edge based features. Multimed Tools Appl 2016; 75:7407-22. [In Persian].

6. Lee PC, Su HN. Investigating the structure of regional innovation system research through keyword co-occurrence and social network analysis. Innovation: Management, Policy, and Practice, 2010; 12: 26-40.

7. Falsafin S, Khavidaki S, Mohammadi M. The Study of Medical Scientific Products of Iran in Web of Science: Literature Review. Payavard 2019; 12:334-346. [In Persian].

8. Vakilimofrad H, Hosseinirad S. Review of Scientific Productions and Mapping the Co-authorship in Scopus Database for Researchers at the Hamadan University of Medical Sciences. Pajouhan Scientific Journal 2018; 16: 53-63. [In Persian]

9. Torkaman T, Shirmohammadi Khorram N. Study the pattern of citation indicators among researchers at Hamadan University of Medical Sciences: Feasibility of predicting citation indicators. CJS 2017; 4 :7-16. [In Persian]

10. Shabankareh Kh, Mansourzadeh MJ, Hamidi A. Scientific impact of Iranian medical sciences universities' research journals in google scholar. Iranian Research Institute for Science and Technology 2018; 2:745-774. [In Persian]

11. Khalili M, Rahmatpour P, Barari F, Hoseinzadeh T. Scientific outputs of Guilan University of Medical Sciences in Scopus database based on scientometrics indicators. J Guilan Uni Med Sci 2016;25:9-16. [In Persian]

12. Sattarzadeh A. Galyani Moghaddam G. Momeni E. Mapping the structure of scientific collaboration networks in basic medical sciences in the Science Citation Index during 1996 to 2013. Knowledge Studies 2016; 2: 1-20. [In Persian]

13. Ranjba-pirmousa Z, Zarei H. Situation of articles published and their citations of Tehran and Shahid Beheshti Universities of Medical Sciences in Web of Science Database. RME 2016; 8:24-33. [In Persian] 
14. Asadi S, Borji Zemeidani N. Analysis and visualization of the scientific relations among Guilan medical research centers, 2015. Available from: http://research.shahed.ac.ir/WSR/SiteData/PaperFiles/43462_4828888972.pdf. [In Persian]

15. Sahmedini MA, Mahmoudi Z, Dehghan Sh. Ranking the Research Centers of Shiraz Medical University Using 5 Scientometrics Indices (H, G, M, R, A) in Scopuse Database. Health Inf Manage 2014; 11: 325. [In Persian]

16. Shekofteh M, Hariri N. Scientific mapping of medicine in Iran using subject category co-citation and social network analysis. JHA 2013; 16:43-59. [In Persian]

17. Ehtesham H. Evaluation of Scientific Output of Researchers at Birjand University of Medical Sciences in Web of Science during 2000-2011. Journal of Birjand University of Medical Sciences. 2012; 9: 324-331. [In Persian]

18. Rasoolabadi M, Khodri A, Heydari A. Status of scientific output of Kurdistan University of Medical Sciences based on scientometric indicators by the end of 2011. Scientific Journal of Kurdistan University of Medical Sciences 2012; 17: 64. [In Persian]

19. Mobasheri M, Moradi M, Rafie S, Sharifi A. Scientific output of Shahrekord university of medical sciences (Iran) in ISI database from 1993 to the end of 2011 according to scientometric indicators. J Shahrekord Univ Med Sci 2013; 14:115-123. [In Persian]

20. Soheili F. Mapping the Structure of Scientific Publication of Tehran Medical University in WOS Database. Health Information Management 2012; 8: 871. [In Persian]

21. Ebrahimi S, Jowkar A. The situation of scientific publications of Iran's Universities of Medical Sciences on the basis of scientometrics qualitative \& quantitative indicators 1997-2006. Health Information Management 2010; 7: 282. [In Persian]

22. Hasanzadeh Esfanjani H, Valinejadi A, Naghipour M, Farshid P, Bakhtyarzadeh A, Bouraghi H. A scientometric overview of 30 years (1978-2007) of medical sciences productivity in Iran. Medical Sciences 2010; 20:212-220. [In Persian]

23. Sobhani A, Tabari R, Tayefeh N. The article publication status among faculty members of Guilan University of Medical Sciences. J Guilan Uni Med Sci 2009; 18 :80-86 .[In Persian]

24. Gorji HA, Roustaazad L, Mohammad hasanzadeh H, Asghari L, Atlasi R, Shokraneh F et al . Ranking of Iran University of Medical Sciences and Health Services' (IUMS) faculties using H-index, G-Index, and m parameter (up to the end of 2008). Journal of Health Administration 2011;13:17-24.

25. Foroughi F, Kharrazi H. Faculty members' scientific productivity in Kermanshah Medical Sciences University. Iranian Journal of Medical Education 2005; 5:181-187 .[In Persian]

26. Aghili A, Aminipour MR, Ahmadieh M, Beiki O. Evaluation of Iranian medical journals by analysing citations to articles published between 1997 and 2000. Hakim Medical Journal 2007;10:36-42. [In Persian]

27. Danesh F, Mesri nejad F. Mapping of medical science research use the Histcite software. Journal of Information Science 2009;3:14-19. [In Persian]

28. Morovati M, Sotudeh H. Scientific productivity in neonates' health field in scopus. Int J Pediatr 2016;4: 1837-46. [In Persian]

29. Osareh S, Shirazi K. A survey on co-authorship network of Iranian researchers in the field of pharmacy and pharmacology in Web of Science during 2000-2012. Health Management 2014;17:84-88. [In Persian]

30. Shirshahi S, Osareh F, Haidari Gh, Loni N. Mapping the structure of surgery discipline in Science Citation Index. Health Inf Manage 2015; 11:839. [In Persian]

31. Jamali J, Dehghani, M, AfzalAghaee, M. Quality of journal of obstetrics and gynecology in ISI and Scopus databases based on indices of ranking journals. The Iranian Journal of Obstetrics, Gynecology and Infertility 2014; 17:9-20. [In Persian]

32. Mirhosseini Z, Vahabi F. Investigating the scientific productions of Iranian type I pharmacy faculty members indexed in the institute for scientific information (ISI). Health Information Management 2011; 8: 372. [In Persian]

33. Eskroochi, R., Ehtesham, H., \& Haghani, H. Scientific productivity of dentistry in Iranian journals during 1978 2006. Iranian Journal of Information Processing and Management 2010;26: 109-19. [In Persian]

34. Ghazi Mirsaid SJ. Determination of the number of dental journals using copyright and attribution rates in open source modeling and cataloging. Dental Journal of Islamic Society of Dentistry 2007; 19: 95-104. [In Persian]

35. Liu Zao, Wan G. Comparing journal impact factor and H-type indices in virology journals. (2012). Library Philosophy and Practice (e-journal). 891. Available from: https://digitalcommons.unl.edu/libphilprac/891. 
36. Bador P, Lafouge T. Comparative analysis between impact factor and h-index for pharmacology and psychiatry journals. Scientometrics 2010 84: 65-79.

37. Kaur H, Gupta B. Mapping of dental science research in India: a scientometric analysis of India's research output 1999-2008. Scientometrics 2010; 85:361-76.

38. Ponce FA, Lozano AM. Academic impact and rankings of American and Canadian neurosurgical departments as assessed using the $\mathrm{h}$ index. J Neurosur 2010:113:447-467.

39. García-García P, López-Muñoz F, Callejo J, Martín-Águeda B, Álamo, C. Evolution of Spanish scientific production in international obstetrics and gynecology journals during the period 1986-2002. Eur J Obstet Gynecol Reprod Biol 2005;123: 150-6.

40. Mirhosseini Z, Vahabi F. Investigating the scientific productions of Iranian type pharmacy faculty members indexed in the institute for scientific information (ISI). Health Inf Manage 2011; 8:363-72. [In Persian] 